\title{
Kültürel Farklılıkların Yönetiminde Kültürel Zekânın Rolü: Türk ve Yabancı Yöneticiler Üzerine Bir Araştırma
}

The Role of Cultural Intelligence on the Management of Cultural Differences: A research on Turkish and Expatriate Managers

\author{
Aslı ERSOY*, Rüya EHTiYAR** \\ * Arş. Gör. T. C. Akdeniz Üniversitesi, Turizm Fakültesi, 07058, Arapsuyu Kampüsü, Antalya \\ E posta: asliersoy@akdeniz.edu.tr \\ ** Doç. Dr., T. C. Akdeniz Üniversitesi, Turizm Fakültesi, 07058, Arapsuyu Kampüsü, Antalya \\ E-posta: ehtiyar@akdeniz.edu.tr
}

MAKALE BILGILERI

Makale işlem bilgileri:

Gönderilme tarihi: 27 Ocak 2014

Birinci değerlendirme: 14 Mart 2014

İkinci değerlendirme: 22 Nisan 2014

Kabul: 26 Nisan 2014

Anahtar sözcükler:

Kültürel zekâ, Kültürel farklılıklar,

Konaklama işletmeleri, Antalya,

Istanbul

\section{ARTICLE INFO}

\section{Article history:}

Submitted: 27 January 2014

Resubmitted: 14 March 2014

Resubmitted: 22 March 2014

Accepted: 26 March 2014

\section{Key words:}

Cultural intelligence, Cultural diffe-

rences, Hospitality industry, Antalya,

Istanbul.
ÖZ

Bu çalışmanın temel amacı, yabancı yöneticilerin kültürel zekâsının kültürel farklılıkların yönetimi üzerindeki etkisini belirlemektir. Bu amaç doğrultusunda İstanbul ve Antalya bölgesinde faaliyet gösteren 10 adet bes yıldızlı konaklama işletmesinin yabancı genel müdürleri ve onlara bağlı olarak çalışan 27 Türk departman müdürüyle derinlemesine görüşme yapılmış ve yarı yapılandırılmış görüşmelerle elde edilen verilerin betimsel analizinden sonra üç ana tema belirlenmiștir. Calıșmada nitel araștırma desenlerinden kültür analizi kullanılmıștır. Araștırma sonuçlarına göre, yabancı yöneticilerin bilișsel, motivasyonel ve davranıșsal kültürel zekâlarının kültürel farklılıkların yönetilmesini olumlu anlamda etkilediği belirlenmiş ve elde edilen bu sonuç da kültürel farklılıkların yönetilmesinde kültürel zekânın önemli bir katkısının olduğunu göstermiştir.

\section{GíRiş}

Bilgi teknolojilerindeki gelişmeler ve küreselleşme sonucu örgütlerin ulusal sınırları aşarak farklı kültürlerde faaliyette bulunmasıyla birlikte farklı etnik köken ve dine sahip bireylerden oluşan gruplar örgütleri daha çeşitli bir hale getirmiştir (Trompenaars ve Hampden-Turner 1997; Harris 2006: 43). Bu

* Bu makale, Aslı Ersoy'un Akdeniz Üniversitesi Sosyal Bilimler Enstitüsü'nde hazırladığ1 "Kültürel Farklllklarn Yönetiminde Kültürel Zekânın Rolüne İlişkin Konaklama İşletmelerinde Bir Araştırma" başlıklı yüksek lisans tezinden üretilmiştir. durum örgütler ve yöneticiler için üstesinden gelinmesi gereken yeni güçlükler ortaya çıkarmış ve örgütlerin kültürel farklılıklara sahip bireyleri etkileyebilme, motive edebilme ve kültürel farklılıkları etkin bir şekilde yönetebilme ihtiyaçları artmıştır. Turizm sektörü, Türkiye'de uluslararası rekabette büyük avantajlara sahip olan stratejik bir sektördür. Sahip olunan tarih ve uygarlik tecrübesi, sosyal dinamizm, kültürel zenginlik ve çeşitlilik dünyada başka bir benzerine rastlanmayacak değerde eşsiz bir coğrafya ile Türkiye, dünya turizminin önemli ve vazgeçilmez bir aktörü olmaya devam 
etmektedir. Turizmin başkenti olarak nitelendirilen Antalya ve dünyanın en önemli zincir otellerinin bulunduğu ve kültürel farklılıkları bünyesinde barındırabilen İstanbul, kültürel farklılığın en fazla yaşandığı turizm destinasyonlarındandır. Böyle bir perspektif içinde kültürel farklılaşmaların uzlaştırılmasına ve avantaja çevrilmesine yönelik yönetim becerileri ve liderlik etkinliği, Türkiye'yi yakından ilgilendirmektedir.

Cox ve Blake (1991: 54), kültürel farklılıklar ve bu farklılıkları yönetmenin hem insanlar hem de örgütler için yararlı olduğunu vurgulamış ve farklılıkların akıllıca yönetilmesi sonucunda birey, grup, örgüt ve toplum açısından fayda getireceğini belirtmiştir. Farklı kültürleri bünyesinde barındıran turizm sektörü için de kültürel farklılıklar ve yönetimi son derece önemlidir. Bu anlamda uluslararası otel yöneticilerinin başarısı için beş anahtar kavram ortaya koyulmuştur (D'Annunzio-Green 1997: 201): Kültürel farkındalık, iletişimsel yeterlilik, bilişsel yeterlilik, değer farklılıklarını anlayabilme ve farklılıklardan sinerjik kazançlar elde edebilme. Konaklama işletmelerinin değişen emek ve müşteri pazarlarında hizmet kalitesi yoluyla rekabet avantajı kazanabilmeleri için farklılıkların yönetilmesi, hem kuramsal hem uygulamalı şekilde temel bir ihtiyaç olarak görülmektedir (Maxwell, McDougall ve Blair 2000: 372).

Kültürel farklılıkların yönetilmesinde çeşitli örgütsel ve bireysel stratejiler vardır. Bu konuda bireysel anlamda en önemli stratejilerden biri de kültürel zekâdır (Early ve Ang 2003; Early ve Mosakowski 2004; Ang ve Van Dyne 2008; Yeşil 2009). Bir bireyin kültürlerarası ortamda veya çok kültürlü bir ortamda etkin bir şekilde işlevini yerine getirmesini ve başarılı olmasını sağlayan yetenekler seti olarak kavramsallaştırılan kültürel zekâ, farklı kültürlerden çalışma gruplarını yönetebilme, farklı uluslardan, farklı kurumlardan ve farklı mesleklerden gelen insanları tanıma, anlama ve birlikte çalişabilmede önemli bir kriter olarak görülmektedir (Early ve Ang 2003: 9).

Kültürel zekâ, günümüzde yönetim ve örgütsel psikoloji alanyazınında oldukça önem kazanmış bir kavramdır. Yönetici ve çalışanların hem birbirleriyle hem de müşterilerle olan ilişkilerinde yeni kültürlere olan etkili uyum becerisini ifade eden kültürel zekânın, 21. yüzyılda yönetici ve çalışanlar için temel bir beceri olduğu ifade edilmektedir.
Kültürel zekâ, hem yöneticilere hem de çalışanlara farklı kültürler karşısında uyum sağlayabilmeyi, karar almayı, doğru iletişim kurmayı, çalışanları etkilemeyi ve yönlendirmeyi daha etkili bir şekilde yapabilme fırsatı sunmaktadır (Sadeghian 2011: 403).

$\mathrm{Bu}$ araştırmanın temel amacı, konaklama işletmelerinde kültürel farklılıkların yönetiminde kültürel zekânın rolünü belirlemektir. Bu araştırma, farklı millet ve kültürden gelen bireylerin ortak bir sinerji yaratabilmelerinde ve iş ortamında başarıyı yakalayabilmelerinde kültürel zekânın rolünün belirlenecek olması bakımından önem taşımaktadır. Bunun yanında turizmle ilgili ulusal ve uluslararası alanyazında konuya ilişkin yapılan çalışmaların sınırlı olması ve konaklama işletmelerinde kültürel farklılıkların yönetimini kültürel zekâ açısından inceleyen Türkiye'deki ilk çalışmalardan biri olma niteliği taşıması nedeniyle araştırma önem teşkil etmektedir.

\section{ALANYAZIN TARAMASI}

\section{Kültürel Zekâ}

Kültürel zekâ, İngilizcede Cultural Intelligence ya da Individual's Cultural Quotient (CQ) olarak ifade edilmektedir. Kültürel zekâ konusunda bugüne kadar çeşitli tanımlamalar yapılmıştır. Early ve Mosakowski (2004: 140), kültürel zekâyı bir bireyin farklı kültürden gelen bir kişinin alışılmadık ve belirsiz olan vücut hareketlerini o kişinin arkadaşları ve aynı kültürde yaşayan insanlar gibi yorumlamasını sağlayan doğal bir yetenek olarak tanımlamıştır. Kültürel zekâ, kültürel meta-biliş ile bağlantılı olan ve bireylerin çevrelerindeki kültürel boyutları şekillendirme, seçme ve uyum sağlamalarına izin veren bilgi ve becerilerin etkileşimli olduğu bir sistemdir (Thomas ve diğerleri 2008: 126). Thomas ve Inkson’a (2006: 78) göre kültürel zekâ, farklı kültüre sahip insanlarla etkin bir şekilde etkileşim kurma yeteneğidir. Kültürel zekâ, bir bireyin yeni kültürel ortamlara adapte olabilme yeteneğidir (Ang ve diğerleri 2007: 336).Kültürel zekâ, çok boyutlu bir kavram olarak üç ya da dört boyut şeklinde ele alınmıştır. Farklı çalışmalarda kültürel zekânın farklı boyutlarının ele alındığı görülmektedir, fakat ortaya koyulan bu boyutların birbiriyle örtüştüğü açık bir şekilde görülmektedir. Bu çalışmada Early ve Ang (2003) tarafından ele alınan meta-bilişsel, bilişsel, motivasyonel ve davranışsal kültürel zekâ boyutları üzerinde durulmuştur: 
Meta-bilişsel kültürel zekâ, farklı kültürlerle karşılaşıldığında liderin strateji oluşturma yeteneğini ifade eder. Meta-bilişsel kültürel zekâ veya strateji oluşturma, yavaş ve dikkatli bir şekilde kendi içimizde ve diğer insanların kafalarının içinde neler olup bittiğini gözlemleme, kendi düşünce süreçlerimiz üzerinde düşünme ve farklı bir kültürü anlamak ve bu durumda meydana gelen problemleri çözmek için kendi kültürel bilgimizden yararlanma yeteneğidir (Van Dyne, Ang ve Livermore 2010: 136).

Bilişsel kültürel zekâ, eğitim ve tecrübe yoluyla elde edilen farklı kültürlerin norm, uygulama ve gelenekleri hakkındaki bilgileri kapsamaktadır. Bu zekâ türü, farklı kültürlerin ve onlara ait alt kültürlerin ekonomik, yasal, sosyal ve genel kültürel değer sistemleri hakkındaki bilgileri içermektedir (Ang ve Van Dyne 2008: 6). Yüksek bilişsel kültürel zekâya sahip olanlar kültürler arasındaki benzerlik ve farklılıkları anlarlar (Ang, Van Dyne, Koh, Ng, Templer, Tay ve Chandrasekar 2007: 338).

Motivasyonel kültürel zekâ, farklı kültürel ortamlarda öğrenmek ve faaliyette bulunabilmek için enerji ve dikkati yönlendirebilme kapasitesi olarak belirtilmiş ve bu motivasyonel kapasitelerin hedefe ulaşmayı kolaylaştıran duygu, bilgi ve davranış kontrolü sağladığı ortaya koyulmuştur (Kanfer ve Heggestad 1997: 39). Yüksek motivasyonel kültürel zekâ, bireyin daha fazla stratejik düşünceyle meşgul olması anlamına gelir ve bu da gerçek uyum üzerinde olumlu bir etki sağlar (Early ve Peterson 2004: 109). Templer, Tay ve Chandrasekar (2005: 157) motivasyonel kültürel zekânın bireylerin kültürlerarası uyum derecesini etkilediğini belirtmişlerdir.

Davranışsal kültürel zekâ, farklı kültürlerden gelen insanlarla etkileşimde bulunurken bir bireyin uygun sözlü ve sözsüz davranışları gösterme yeteneğidir. Davranışsal kültürel zekâ, geniş anlamda bir davranış repertuarına sahip olmayı gerektirir (Van Dyne, Ang ve Koh 2008: 17). Davranışsal kültürel zekâsı yüksek olan bireyler esnektir ve davranışlarını farklı kültürel etkileşimlere göre ayarlayabilirler (Ang ve Van Dyne 2008: 7).

\section{Kültürel Zekâ ve Kültürel Farklılıkların Yönetimi}

Globalleşme sonucunda ulusal boyuttan uluslararası boyuta taşınan işletmeler için farklı kültürlere sahip birey ve grupları yönetmek önemli hale gelmiştir. Buna göre, farklı kültürel özellikler taşıyan işgücünü herkesin paylaşabileceği ortak değerler etrafında birleştirerek, kültürel farklılığ $\breve{1}_{1}$ işetme için bir avantaja dönüştürmek işletme etkinliğinin sağlanmasında olmazsa olmaz koşullardan biri haline gelmiştir (Ehtiyar 2003: 67).

Kültürel farklılıkların yönetimi, örgütün amaçlarına ulaşmasını sağlamak için tüm iş görenlerin kendi potansiyellerini tam olarak kullanmalar1na olanak verecek bir ortam yaratmayı amaçlayan bütünselci bir odaklanmadır (Seymen 2005: 10). Konaklama işletmeleri farklılıkları bünyesinde barındıran bir yapıya sahiptir. Yapılan araştırmalarda en etkili organizasyonların tek bir kültüre taraftar olma eğiliminden kaçınan ve bulundukları ülkenin kültürünü dikkate alan bir yaklaşıma sahip oldukları belirlenmiştir (Vincere 1995: 2). Yapılan bir başka araştırmada da benzer sonuçlara ulaşılmış olup konaklama endüstrisinin değişen yapısıyla birlikte tek kültürlülük yerine çok kültürlü yapıyı esas alan bir yaklaşıma sahip oldukları belirlenmiştir (Christensen Hughes 1992). Kültürel farklılıkların etkin yönetimi konaklama endüstrisi açısından son derece önemli görülmektedir. Konaklama işletmelerinde rekabet avantajı sağlayabilmek kültürel farklılıkların etkin yönetilmesiyle sağlanabilir (Maxwell vd. 2000).

Farklı kültürlerden gelen yöneticiler ve çalışanlar arasında tutum, davranış ve motivasyon yönünden farklılıklar olup olmadığ 1 ve bu farklılıkların grubun yönetimi ve performansı üzerinde ne gibi etkiler yarattığ 1 konusunda birçok çalışma yapılmıştır (Chen, Chen ve Menioll 1998; Hofstede 1980). Asunakutlu ve Safran (2004), turizm işletmelerinde kültürel farklılıkların iyi yönetilmediği takdirde çatışmaya neden olabileceğini belirlemiştir. Mok, Pine ve Pizam (1998) tarafından Hong Kong'da bulunan otel işletmelerinde görevli yabancı yöneticiler üzerinde yapılan bir çalışmada yöneticilerin karar verirken kendi ülkelerinin değerlerine uygun tarzda hareket etme eğiliminde olduğu belirlenmiştir. Bu durum olumsuz sonuçları beraberinde getirmektedir. Özellikle ilk defa giriş yaptığı bir ülkenin ya da bölgenin kültürüne yabancı olan bir uluslararası işletmenin, başarılı olabilmesi için belki de ilk yapması gereken o toplumun kültürünü etüt etmek ve çalışanlarına ve o topluma karşı bu değerleri göz önüne alarak davranış biçimi geliştirmektir (Aksu ve Ehtiyar 2007: 184). 
Hughes (1999) tarafından Kanada'da yapılan bir çalışmada kültürel farklılıkların etkin bir şekilde yönetilmesinin yöneticiler açısından zorlayıcı bir süreç olduğu fakat bunun gerekli olduğu ortaya koyulmuştur. Lundberg ve Woods (1990) tarafından yapılan bir araştırmada ise kültürel duyarlılığa sahip yöneticilerin daha başarılı oldukları belirlenmiştir. Bu bağlamda başarılı bir evrensel yönetici her şeyden önce kozmopolit bir yapıya sahip olma$l_{1}$ ve merkeziyetçi (etnosentrik) olmamalıdır. Başka bir deyişle, farklı kültürlerden gelen insanlara açı ve esnek olmalı ve onları kategorileştirip dışlamamalıdır (Aksu ve Ehtiyar 2007: 189).

Kültürlerin iç içe yaşandığı bir ortamda, karışıklık, yanlış anlaşılmalar, mahcup olma, haksız duruma düşme hissi, ilişkilerde bozulma sık sık meydana gelir ve işyeri sorunlarına neden olur. Bu durum genellikle çalışanların başarılı bir yönetim için gereken bir beceri olan kültürel zekâya sahip olmamasından kaynaklanır (DuPlesis 2011: 28). Triandis (2006: 20), farklı kültürlerde başarılı bir şekilde etkileşim kurmak için kültürel zekânın gerekli olduğunu belirtmiştir.DuPlessis (2011: 30) ise kültürel zekânın yönetici ve liderlerin stratejik yeteneğine ve organizasyona katkı sağladığını vurgulamıştır. Bunun yanında yapılan araştırmalar etkin kültürlerarası liderliğin sadece duygusal zekâ ve sağduyu meselesi olmadığını göstermektedir (Ang, Van Dyne, Koh, Ng, Templer, Tay ve Chandrasekar 2007).

Kültürel farklılıkların başarılı bir şekilde yönetilmesinde liderlerin kültürel zekâ seviyelerinin de etkisi bulunmaktadır. Güçlü kültürel zekâ yetenekleri, liderlerin çalışma ekiplerinin ihtiyaçları ve perspektifleri için daha doğru bir anlayış geliştirmelerine izin verir ve sonuç olarak kültürel farklılığa sahip takım üyeleriyle güçlü ilişkiler kurulmasina yardımci olur (Groves ve Feyerherm 2011: 541542). Yüksek kültürel zekâ, liderlerin pozitif bir ortam yaratmalarına, farklı kültürlerde çalışırken en iyi sonucu verecek olan takım üyelerinin becerilerinden yararlanmalarına ve yüksek performanslı takımlar geliştirmelerine yardımcı olur (MacClachlan, 2011).

Yapılan araştırmalarda, kültürel zekânın bireylerin kültürlerarası performanslarına katkı sağladığ 1 (Ang, Dyne, Koh, Ng, Templer, Tay ve Chandrasekar 2007; Şahin ve Gürbüz 2011), kültürlerarası adaptasyonda etkili olduğu (Templer, Tay ve Chandrasekar 2006), tükenmişliği azalttığı (Tay,
Westmen ve Chia 2008) ve başarıyı arttırdığı (Vedadi, Kheiri ve Abbasalizadeh 2010) görülmüştür. Deng ve Gibson (2008), kültürlerarası liderlik etkinliğiyle ilgili yaptıkları nitel bir araştırmada, liderin kültürel zekâsının farklı kültürel geçmişi olan astları yönetmede önemli olduğunu bulmuşlardır. Farklı kültürlerden kişilerin oluşturduğu takımlarda yapılan bir çalışmada, liderin kültürel zekâsının liderlik performansına ve takım çalışmasına olumlu yönde katkıda bulunduğu görülmüştür (Groves ve Feyerherm 2011). İsviçre ordusunda uluslararası askerî operasyonlarda görevlendirilen subaylar arasında yapılan bir araştırmada ise kültürel zekânın, genel bilişsel zekâ ile duygusal zekâdan daha fazla kültürlerarası liderlik için önemli olduğu ortaya çıkmıştır (Rockstuhl vd. 2011). Bunun yanında, kültürel zekânın uluslararası liderlik potansiyelinin belirleyicisi olduğu yapılan araştırmalarla da ortaya koyulmuştur (Kim ve Van Dyne 2012).

Ulusal alanyazında, kültürel zekâya ilişkin olarak yapılan çalışmalar bulunmakla birlikte, bunlar kültürel zekâ olgusunu derinlemesine anlamada sayı ve kapsam bakımından yetersiz kalmaktadır. Yeşil (2009; 2010), küresel örgütler için ve kültürel farklilıkların yönetiminde alternatif bir strateji olarak kültürel zekâ konusunu kavramsal açıdan ele almıştır. Şahin (2011), liderlerin kültürel zekâsının astların örgütsel vatandaşlık davranışı ve iş doyumu üzerine etkisini belirlemeye yönelik bir çalışma ortaya koymuştur. Sonuç olarak, kültürlerarası ortamda bir liderin kültürel zekâsının astların örgütsel vatandaşlık davranışı ile iş doyumunu olumlu yönde etkilediği bulunmuştur. Şahin ve Gürbüz (2012), kültürel zekâ ve öz-yeterliliğin görev performansı ve örgütsel vatandaşlık davranışı üzerindeki etkisini belirlemeye yönelik bir çalışma yapmışlardır. Sonuç olarak, kültürel zekânın ve özyeterliliğin gerek görev performansını gerekse örgütsel vatandaşlık davranışını olumlu yönde etkilediği sonucuna varmışlardır.

\section{ARAŞTIRMANIN YÖNTEMI}

\section{Araştırma Modeli}

Araştırmada yabancı yöneticilerin kültürel zekâsının kültürel farklılıkların yönetimi üzerindeki etkisini belirlemek amacıyla nitel araştırma desenlerinden kültür analizi kullanılmıştır. Farklı kültürlerde iş görme ve liderlik etkinliği üzerine 
odaklanan bu araştırmanın deseni bireylerin ya da grubun kültürünü (değerler, inançlar ve uygulamalar) ve bu kültürün davranışları nasıl etkilediğini betimlemeye ve açıklamaya olanak tanıması nedeniyle kültür analizi olarak tasarlanmıştır. Bu araştırma yukarıda belirtilen amacı ve soruları açısından kültürel anlamda derinlemesine betimlemeleri gerektirdiğinden nitel bir araştırma olarak tasarlanmıştır.

Kültür analizi, bireysel algı ve davranışın olduğu kadar toplumsal davranış, yapı, işleyiş, değerler, normlar gibi kültürel öğelerin tanımı ve analizi üzerine odaklanmaktadır. Kültür analizine yönelik çalışmalarda amaç belirli bir grubun kültürünü tanımlama ve yorumlamadır. Veri kaynakları genellikle bir kültürü oluşturan ve o kültürden etkilenen bireyler ya da gruplardır (Yıldırım ve Şimşek 2006: 70-71).

\section{Veri Toplama Aracı}

Araştırmada nitel veri toplama tekniklerinden derinlemesine görüşme (mülâkat) tekniği uygulanmış ve bu amaçla yarı yapılandırılmış görüşme formundan yararlanılmıştır. Derinlemesine görüşmede grup baskısı ortadan kalktı̆̆ için her katılımcı düşüncelerini daha dürüstçe ortaya koyar. Bunun yanında katılımcı yüz yüze görüşmeye daha çok ilgi gösterir çünkü anketörle doğrudan ilişki içindedir ve arkasında saklanacağı başka grup üyeleri yoktur (Proctor 2005: 221).

Yarı yapılandırılmış görüşme tekniğinde araştırmacı önceden sormayı planladığı soruları içeren görüşme protokolünü hazırlar. Buna karşın araştırmacı görüşmenin akışına bağlı olarak değişik yan ya da alt sorularla görüşmenin akışını etkileyebilir ve kişinin yanıtları açmasını ve ayrıntılandırmasını sağlayabilir (Türnüklü 2000: 6). Yarı yapılandırılmış görüşme tekniğinin araştırmaciya sunduğu en önemli kolaylık görüşmenin önceden hazırlanmış görüşme protokolüne bağlı olarak sürdürülmesi nedeniyle daha sistematik ve karşılaştırılabilir bilgi sunmasıdır (Yıldırım ve Şimşek 2004: 283).

\section{Soru Formunun Hazırlanması}

Soru formu geliştirilirken ilgili ulusal ve uluslararası alan yazın araştırmalarından (Early ve Mosakowski 2004; Deng ve Gibson 2008; Yeşil 2009; Groves ve Feyerherm 2011; DuPlessis 2011; Şahin ve Gürbüz 2012) ve uzman görüşlerinden yararlanılmıştır. Meta-bilişsel kültürel zekâ, bilişsel kültürel zekânın daha üst bir boyutu olarak düşünüldügünden, bilişsel kültürel zekâ boyutunun yanıtı alınmak istenen soruları karşılar nitelikte olduğu görülmüş ve çalışma bilişsel, motivasyonel ve davranışsal kültürel zekâ olarak üç boyutta ele alınmıştır. Araştırmanın amacı doğrultusunda aşağıdaki sorulara yanıt aranmıştır:

\section{Yabancı Yöneticilere Ait Sorular}

1-Türk kültürü ve kendi kültürünüz arasındaki bazı tipik farklılıkları tanımlayabilir misiniz?

2-Türkiye'de çalışmaya başlamadan önce Türk kültürü ile ilgili bilgili miydiniz?

3- İçinde yaşadığınız ülkenin kültürünü daha iyi anlayabilmek için o ülkenin dilini öğrenme yolunda bir çabanız var mı?

4-Siz deneyimli bir yönetici olarak, genç yönetici adaylarına yabancı bir kültürde yaşama ve çalışma konusunda neler önerirsiniz?

5-İçinde bulunduğunuz kültüre adaptasyon sürecinde hangi zorlukları yaşadınız ya da yaşıyorsunuz?

6- Motivasyon araçlarını kullanırken Türk kültüründe bir çalışanı güdüleyen araçları biliyor musunuz ve uygulamada nasıl bir yol izliyorsunuz?

7- İş dışında çalışanlarınızla vakit geçiriyor musunuz?

8-İletişim kurarken en fazla yaşadığınız sıkıntılar nelerdir (vücut dili, iletişimin açık ya da kapalı olması, kullanılan sembolleri bilmemek)?

9-Kendi kültürünüzün baskın değerlerini Türk kültürüne uyarlamak gibi bir çabanız var mı?

\section{Türk Departman Müdürlerine Ait Sorular}

1-Yabancı bir yöneticiyle çalışmanın zorlukları ve kolaylıkları var mıdır? Varsa nelerdir?

2-Yabancı yöneticinizin sizin kültürünüze karşı tutumu ya da anlayışı sizin için ne derece önemlidir?

3-Yabancı yöneticiniz Türk kültürünü anlayabiliyor mu, bu kültüre uygun üretken davranış sağlamaya yönelik ne tür tutum içerisine giriyor?

4- Siz mi yabancı yöneticinizin kültürünü anlamaya çalışıyorsunuz yoksa o mu sizin kültürünüzü anlamak için çaba sarf ediyor?

5-Yabancı yöneticinizle iş dışında da zaman geçiriyor musunuz? 


\section{Örneklem}

Araştırmada amaçlı örnekleme yöntemlerinden maksimum çeşitlilik örneklemesi kullanılmıştır. Miles ve Huberman (1994: 27), nitel araştırmalarda örneklemi derinlemesine araştırabilmek için örneklem grubunun küçük olduğunu, bu nedenle rasgele örneklem seçimi yerine, amaçlı örnekleme tercih edildiğini belirtmiştir (Akt. Tekbıyık ve Akdeniz 2008: 26). Maksimum çeşitlilik örneklemesindeki amaç göreli olarak küçük bir örneklem oluşturmak ve bu örneklemde çalışılan probleme taraf olabilecek bireylerin çeşitliliğini maksimum derecede yansıtmaktır (Yıldırım ve Şimşek 2006: 108).

Bu araştırma için örneklem belirlenirken beş yıldızlı konaklama işletmelerinde görevli yabancı otel genel müdürleri ve onlara bağlı olarak çalışan Türk departman müdürleri uygun bir katılımcı profili olarak kabul edilmiş ve ilk olarak Antalya ve İstanbul illerinde bu profile uygun işletmeler tespit edilmeye çalışılmıştır. Bu aşamada İl Turizm Müdürlüklerinden yardım alınmıştır. Yabancı yönetici örneklemi, aynı zamanda Türk çalışanların örneklemini de belirleyen bir işlev üstlenmiştir. Antalya yöresinde belirtilen özelliğe sahip dört konaklama işletmesi, İstanbul yöresinde ise 11 konaklama işletmesi belirlenmiştir. Bu bölgelerin seçilme nedeni ise yabancı yönetici sayısı bakımından bölgede en yoğun çekim merkezi olmalarından kaynaklanmaktadır. Antalya yöresinde belirtilen özellikteki dört konaklama işletmesinin tamamından, İstanbul yöresinde ise belirtilen özelliklere sahip altı konaklama işletmesinden olumlu yanıt alınmıştır. Diğer konaklama işletmelerinden işletme kararları ve politikaları sebebiyle araştırma kapsamına dâhil olmaları konusunda olumlu yanıt alınamamıştır.

Çalışma bağlamında her bir konaklama işletmesi genel müdüründen ve onlara bağlı olarak çalışan Türk departman yöneticilerinden randevu alınmış ve onlarin belirledikleri tarih ve saatte bulundukları konaklama işletmelerinde görüşme gerçekleştirilmiştir. Görüşmeler 01 Nisan-28 Mayıs 2013 tarihleri arasında tamamlanmıştır. Görüşmeler ortalama 40 dakika sürmüştür. Yabancı katılımcılara yönelik görüşmeler bir uzman eşliğinde İngilizce gerçekleştirilmiş ve daha sonra Türkçeye çevrilerek analize hazır hale getirilmiştir. Görüşmeler her bir katılımcıya görüşme formunda yer alan açık uçlu soruların sorulması ve alınan yanıtların katılımcının izni doğrultusunda ses ve görüntü kaydı yapan bir cihaza kaydedilmesi şeklinde gerçekleştirilmiştir. Bunun yanında görüşmeler yazılı olarak da not edilmiştir.

\section{Geçerlilik ve Güvenilirlik}

Geçerlilik ve güvenilirlik, araştırma sonuçlarının inandırıcılığı açısından en yaygın olarak kullanılan iki ölçüttür. Araştırmacının araştırdığı olguyu, olduğu biçimiyle ve olabildiğince yansız gözlemesi nitel araştırmalarda geçerlilik anlamına gelmektedir (Kirk ve Miller 1986; Akt. Yıldırım ve Şimşek 2006: 255). Geçerlilik konusunda nitel araştırmacıya sunulan stratejileri, iç ve diş geçerlilik olmak üzere iki ayrı bölümde incelemek mümkündür.

Araştırma kapsamında iç geçerliliğin sağlanması için; araştırma bulguları verilerin elde edildiği ortama bağlı olarak tanımlanmış, araştırma ile ilgili olarak alan yazın sürekli okunmuş, bu doğrultuda araştırmanın kavramsal çerçevesi oluşturulmuş, veri toplama araçları oluşturulurken alan yazın okunmuş ve görüşmelerden elde edilen verilerden doğrudan alıntılar verilmiş, ardından yoruma gidilmiştir. Araştırma kapsamında dış geçerliliğin sağlanması için; araştırmanın modeli, çalışma grubu, veri toplama araçları, veri toplama, çözümleme ve yorumlama sürecine ilişkin özellikler başka örneklemlerle karşılaştırma yapılabilecek düzeyde ayrıntılı olarak tanımlanmış, araştırma sonuçları okuyucunun sonuçları kendi deneyimleriyle ilişkilendirebilecek şekilde sunulmuş ve araştırma bulgularının başka araştırmalarda test edilebilecek düzeyde olması için sürece ilişkin gerekli açıklamalar yapılmıştır. Araştırmada güvenilirlik iki anlama gelmektedir. Birincisi, araştırma yönteminin güvenilirliğini ifade eder. Bu tamamen yöntemle ilgilidir. İkinci anlamı ölçülecek nesnenin, olgunun ya da tutumun boyutlarının, miktarının ya da düzeyinin tam ve doğru olarak ölçülmesini ifade eder (İslamoğlu 2009: 129).

Araştırmada iç güvenilirliğin sağlanması için; veriler betimsel bir yaklaşımla sunulmuş, görüşme yoluyla elde edilen veriler yorum katılmadan doğrudan alıntılarla sunulmuş ardından gerekli durumlarda yorumlara sonradan yer verilmiş, alan yazında araştırma ile ilgili yapılmış diğer çalışma sonuçları bu araştırma ile ulaşılan sonuçların güvenilirliğini teyit etmede kullanılmış ve verilerin analiz sürecine ilişkin bilgiler açık ve ayrıntılı bir biçimde verilerek iç güvenilirliğin artması sağlan- 
mıştır. Araştırmada diş güvenilirliğin sağlanması için; nitel yapının nasıl oluşturulduğu, veri toplama araçlarının neler olduğu, oluşturulma süreci, verilerin toplanma sürecinde görüşmelerin nasıl yapıldığı, görüşme verilerinin araştırmacı tarafından alınan notlarla kaydedildiği ve verilerin betimsel analizinde izlenen aşamalara yer verilmiştir.

\section{Verilerin Analizi}

Katılımcılardan elde edilen verilerin çözümlenmesinde betimsel analiz yöntemi kullanılmıştır. Betimsel analiz, elde edilen verilerin daha önceden belirlenen temalara göre özetlenip yorumlanması yaklaşımıdır. Doğrudan alıntılara sık sık yer verilen bu yaklaşımda görüşülen ya da gözlenen bireylerin görüşlerini çarpıcı bir şekilde yansıtmak amacı güdülür (Yıldırım ve Şimşek 2006: 224). Görüşmeler tamamlandıktan sonra elde edilen yazılı kayıtların bilgisayar dökümü yapılmıştır. Bunun için veriler öncelikle bilgisayar ortamına aktarılıp gerekli yüklemeler yapılmış ve soru bazında bir sinıflandırma yapılarak toplanan veriler betimsel analiz için hazır hale getirilmiştir.

\section{ARAŞTIRMA BULGULARI}

Araştırma, beş yıldızlı konaklama işletmelerinde görevli 10 yabancı genel müdür ve onlara bağlı olarak çalışan 27 Türk departman müdürleriyle gerçekleştirilmiştir. Birinci aşama beş yıldızlı konaklama işletmelerinde çalışan yabancı genel müdürleri, ikinci aşama ise yabancı yöneticilere bağlı olarak çalışan Türk departman müdürlerini kapsamaktadır.

\section{Yabancı Yöneticilere Ait Bulgular}

Bu bölümde yabancı genel müdürlerin kültürel zekâsı ve kültürel farklılıkları yönetme becerisine dayanan bulgular sunulmuştur. Yabancı katılımc1lar görüşme sırasına göre K1, K2, K3, K4, K5, K6, $\mathrm{K} 7, \mathrm{~K} 8$, K9 ve K10 şeklinde sıralanmıştır.

\section{Yabancı Yöneticilere Ait Demografik Özellikler}

Araştırmaya katılan yabancı yöneticilerin demografik özellikleri Tablo 1'de aşağıdaki gibi sunulmuştur.

Araştırma kapsamında yer alan beş yıldızlı konaklama işletmelerinde genel müdür pozisyonunda çalışan toplam 10 yöneticinin tamamı erkektir. Yabancı genel müdürlerden sadece biri Avusturyalı iken iki Alman, üç İspanyol, iki Hollandalı ve iki İtalyan yönetici araştırmaya katılmıştır. Araştırmaya katılan yöneticilerin yaş ortalaması 46 olup Türkiye'de çalışma süreleri ortalama altı yıldır. Yöneticilerin altısının İstanbul'da ve dördünün Antalya'da aileleriyle birlikte yaşadıkları belirlenmiştir. Bunun yanında yabancı yöneticilerin tamamı daha önce farklı ülkelerde çalışma deneyimine sahiptir.

\section{Yabancı Yöneticilerin Kültürel Zekâ ve Kültürel Farklılıkları Yönetme Becerilerine İlişkin Bulgular}

Araştırmada kullanılan görüşme formu aracılığıyla 10 konaklama işletmesi genel müdürüyle gerçekleştirilen görüşmelerin notları deşifre edilmiş ve

Tablo 1. Yabancı Yöneticilerin Demografik Özellikleri

\begin{tabular}{lccccc}
\hline Katılımı & Cinsiyeti & Milliyeti & Yaşı & $\begin{array}{c}\text { Türkiye'de } \\
\text { çalışma süresi }\end{array}$ & Şehir \\
\hline K1 & Erkek & Avusturya & 41 & 7 yıl & Antalya \\
\hline K2 & Erkek & Almanya & 46 & 28 yıl & Antalya \\
\hline K3 & Erkek & Almanya & 56 & 3 ay & Antalya \\
\hline K4 & Erkek & İspanya & 52 & 8 yıl & Antalya \\
\hline K5 & Erkek & İspanya & 44 & 1 ay & İstanbul \\
\hline K6 & Erkek & İspanya & 45 & 5,5 yıl & İstanbul \\
\hline K7 & Erkek & Hollanda & 52 & 2,5 yıl & İstanbul \\
\hline K8 & Erkek & Hollanda & 38 & 3,5 yıl & İstanbul \\
\hline K9 & Erkek & İtalya & 40 & 10 yıl & İstanbul \\
\hline K10 & Erkek & İtalya & 48 & 2 yıl & İstanbul \\
\hline
\end{tabular}


kültürel zekânın her boyutu için öne çıkan temalar belirlenmiştir. Buna göre bilişsel, motivasyonel ve davranışsal kültürel zekâ boyutları altında oluşan temalar ve tema içerikleri tablolaştırılmıştır.

\section{Bilişsel Kültürel Zekâ Boyutu}

Yabancı yöneticilerle yapılan görüşmelerin sonucunda bilişsel kültürel zekâ kapsamında üç konunun öne çıtı̆̆g görülmektedir: Yabancı yöneticilerin kendi kültürleriyle Türk kültürü arasında gördükleri en önemli farklılıklar; Türkiye'ye gelmeden önce alınan kurumsal oryantasyon ve bireysel hazırlik süreçleri ve Türkçenin öğrenilmesidir. Bu alt boyutların içerikleri ile ilgili yapılan saptamalar Tablo 2'de gösterilmiştir.

$\mathrm{Bu}$ tespitlere göre yabanc1 yöneticilerin kendi kültürleriyle Türk kültürü arasında gördükleri en önemli farklılıklar din, duygusallık, kurallara uymama ve genel yaşam koşullarındaki farklılıklardır. Diğer taraftan bilişsel kültürel zekânın boyutlarından biri olan oryantasyon sürecinde ise yabanc1 yöneticilerin Türk kültürüne daha çok bireysel çabalarla uyum sağlamaya çalıştıkları izlenmektedir. Araştırmaya katılan yabancı yöneticilerin Türkiye'ye gelmeden önce ve geldikten sonra herhangi bir kurumsal oryantasyona tabi tutulmadıkları belirlenmiştir.

Bununla da ilişkili görülebilecek dil öğrenme sürecinde ise yabancı yöneticilerin işyerinde kendi dillerini ya da İngilizceyi ağırlıkta kullansalar da Türkçeyi öğrenmeye çaba gösterdikleri ve bu çabayı özellikle Türk çalışanlarla iyi ilişkiler kurabilmek için önemli buldukları anlaşılmaktadır. Nitekim uzun süreden beri Türkiye'de yaşayan yabanc1 yöneticilerin iyi derecede Türkçe konuştuğu ve diğer yabancı yöneticilerin büyük bir kısmının ise Türkçeyi öğrenme konusunda çaba gösterdikleri belirlenmiştir.

\section{Motivasyonel Kültürel Zekâ Boyutu}

Farklı bir kültürle ilgilenme, uyum için niyet, istek ve çaba gösterme gönüllüğüne yönelik potansiyeli ifade eden motivasyonel kültürel zekâ kapsamında üç konu öne çıkmıştır: Yabancı yöneticilerin uyum sürecinde yaşadıkları zorluklar, Türk çalışanları motive eden unsurlar ve çalışanlarla informal ilişkilerdir. Bu alt boyutların içerikleri ile ilgili yapılan saptamalar Tablo 3'te gösterilmiştir.
Elde edilen bulgulara göre yabancı yöneticilerin kültürel uyum sürecinde yaşadıkları en önemli sorunun içinde yaşadıkları kültürün dilini ve insanların vücut dilini bilmemeleri olduğu belirlenmiştir. Yabancı yöneticilerin bir kısmının, Türk çalışanların duygusal olmasindan ve kendilerini yeterince ifade edememelerinden kaynaklanan zorluklar yaşadıkları belirlenmiştir. Bulgular, yabancı yönetici ve Türk departman yöneticileri arasındaki etkili iletişimin sadece kültürü anlamak için değil aynı zamanda yerel kültüre uyumda da etkili olduğunu ortaya koymaktadır.

Yabancı yöneticiler Türk kültüründe bir çalışanı motive eden aracı, çalışanlara karşı açık ve içten olmak, onları dinlemek, onları düşündüğünü hissettirmek ve dokunmak şeklinde nitelendirmişlerdir. Bunun yanı sıra yöneticiler, çalışanları motive eden araçların kültürel özelliğe indirgenemeyeceğini, motivasyon araçlarının evrensel olduğunu da vurgulamışlardır. Öte yandan yabancı yöneticilerin büyük bir çoğunluğunun iş dışında çok sık olmasa da çalışanlarıyla zaman geçirdikleri belirlenmiştir. Yöneticilerin bir kısmının ise turizm sektörünün özelliğinden kaynaklanan uzun iş saatlerinden dolayı ve Türk çalışanların iş ve arkadaşlığ 1 birbirine karıştırmasından dolayı iş dışında fazla zaman geçirmedikleri belirlenmiştir.

\section{Davranışsal Kültürel Zekâ Boyutu}

Belirli bir kültürel ortama uygun olan davranışları içeren davranışsal kültürel zekâ kapsamında iki konunun öne çıktı̆̆1 görülmektedir: İletişim zorlukları ve kültürel görelilik. Bu alt boyutların içerikleri ile ilgili yapılan saptamalar Tablo 4 'te gösterilmiştir.

Elde edilen verilere göre yabancı yöneticilerin büyük bir kısmının iletişim anlamında yaşadıkları sıkıntının vücut dilini ve içinde yaşadıkları kültürün dilini bilmemelerinden kaynaklandığı belirlenmiştir. Türkçe bilmeyen yabancı yöneticilerin İngilizce olarak iletişim kurdukları görülmektedir. Bazı yabancı yöneticilerin içinde yaşadıkları kültürün dilini bilmeseler bile vücut diliyle de iletişim kurabildiklerini belirtmiş olmaları, iletişimin sadece sözlü bir eylem olmadığını ortaya koyar niteliktedir. Katılımcıların bir kısmı ise Türk çalışanların fikirlerini açık bir şekilde ifade edememelerinden dolayı sıkıntı yaşadıklarını belirtmişlerdir. 
Tablo 2. Bilişsel Kültürel Zekâ Boyutuna İlişkin Bulgular

\begin{tabular}{|c|c|c|}
\hline Alt Boyutlar & İçerikler & Örnek Ifadeler \\
\hline \multirow[t]{2}{*}{$\begin{array}{l}\text { Türk ve } \\
\text { Diğer Kültürler Arasındaki } \\
\text { Farklılıklar }\end{array}$} & \multirow[t]{2}{*}{$\begin{array}{l}\text { Din, duygusallık, } \\
\text { kurallara uymama ve } \\
\text { genel yaşam koşulları }\end{array}$} & $\begin{array}{l}\text { "En önemli farklılık din. Bence yaşama koşulları açısından da farklııık var. } \\
\text { Avusturya'da yaşama koşulları daha iyi. Türkiye'de kötü demek } \\
\text { istemiyorum ama farklı. Avusturya'da nasıl büyüdüğünle Türkiye'de } \\
\text { nasıl büyüdüğünün farkı var. Fikirler, anlayışlar bunun gibi birçok farklıık } \\
\text { yaşıyoruz."(Avusturyalı Yönetici) }\end{array}$ \\
\hline & & $\begin{array}{l}\text { "Bana göre en belirgin fark kuralların izlenmesinde ortaya çıkıyor. } \\
\text { Örneğin, Hollanda'da birtakım kurallar vardır uyulması gereken ve } \\
\text { bu kurallara uyulur. Benim ülkemde ya da Avrupa'da kuralları yerine } \\
\text { getirmezsen yaptığın işi ciddiye almadığın anlamına gelir. Türkiye'de } \\
\text { kurallar pek fazla ciddiye alınmıyor. Bazıları uyuyor, bazıları } \\
\text { uymuyor.”(Hollandalı Yönetici 1) }\end{array}$ \\
\hline
\end{tabular}

"Ben Hollanda kültüründe doğdum ve büyüdüm. Kendi kültürüm ve Türk kültürü arasındaki en belirgin fark Türkler Almanlara göre daha duygusal. Bunun yanında Türkiye'de ilişkiler çok önemli. Hollanda'da her şey belli kurallara göre yapılır ve iş ortamında duygusallık aranmaz. Türkler için iş ortamında bile arkadaşıı önemli ama benim kültürümde iş ve arkadaşığın belirli çizgileri vardır." (Hollandalı Yönetici 2)

\begin{tabular}{lll}
\hline Oryantasyon Süreci & $\begin{array}{l}\text { Türkiye'ye gelmeden } \\
\text { önce alınan kurumsal } \\
\text { oryantasyon eğitimleri } \\
\text { ve bireysel hazırıklar }\end{array}$ & $\begin{array}{l}\text { "Hayır, bilgili değildim. Türkiye'ye ve kültürünü öğrenmeye yönelik } \\
\text { bireysel bir çabam olmadı. Kurumsal anlamda da herhangi bir } \\
\text { oryantasyon eğitimi almadım, sadece Türkiye hakkında kitapçık } \\
\text { ve broşür verildi. Türkiye'de çalışmaya başladıktan sonra Türk kültürü } \\
\text { hakkında bilgi sahibi olmaya başladım."(Avusturyalı Yönetici) }\end{array}$ \\
\cline { 2 - 2 }
\end{tabular}

"Evet, eşim Türk ve dolayısıyla Türk kültürü hakkında bilgili olarak geldim. Bunun yanında Hollanda'da yaşayan çok yakın bir Türk arkadaşımdan ülke hakkında birçok bilgi edinmiştim gelmeden önce."(Hollandalı Yönetici 2)

"Hayır, bilgili değildim. Biz genel müdürler olarak dünyayı dolaşıyoruz ve bu sırada gittiğimiz ülkelerin kültürlerini öğrenmeye çalışıyoruz. Türkiye'ye geldikten sonra kültürünü ve insanlarını öğrenmeye başladım, fakat kurumsal anlamda bir oryantasyon eğitimi almadım. "(İtalyan Yönetici 2)

"Şunu kesin bir şekilde söyleyebilirim ki içinde yaşadığınız ülkenin kültürünü anlayabilmek için o dili bilmek gerekiyor. Birçok dil biliyorum ama çok az Türkçe konuşuyorum. Eğer çalışanlarla Türkçe konuşmazsak emin olun çok problem yaşarız. Türkçe öğrenmeye çalışıyorum ve de öğrenmek istiyorum." (Avusturyalı Yönetici)

“İşyerinde büyük çoğunlukla İngilizce kullanıyorum. İspanyolca konuşulmayan yerlerde özellikle İngilizce kullanıyorum. Dil öğrenmenin kültürü anlama konusundaki etkisi yadsınamaz. 5 yıldır Türkçe eğitimi alıyorum ve çalışanlarla Türkçe konuşmaya da özen gösteriyorum." (İspanyol Yönetici 1)

"Ben altı dil biliyorum. Ofisime kim gelirse onun dilinde konuşmayı tercih ediyorum. Dil kültürü anlama ve yorumlamada önemli bir etken. Şu an iyi derecede Türkçe konuşuyorum ve bu iş ortamındaki ilişkilerime de olumlu bir şekilde yansıyor." (İtalyan Yönetici 1) 
Tablo 3. Motivasyonel Kültürel Zekâ Boyutuna İlişkin Bulgular

\begin{tabular}{lll}
\hline Alt Boyutlar & lçerikler & Örnek Ifadeler \\
\hline Uyum Sürecinde & Yabancı dil bilmemek, & "Türk kültürüne adapte olmak için insanları değiştiremem, ama kendimi \\
Yaşanan Zorluklar & vücut dilini bilmemek, & değiştirmeliyim dedim. Her şeye açık olmak zorundasınız ve kendi \\
& iletişim problemi, & ülkenizle içinde yaşadığınız ülkenin değerlerini karşılaştıramazsınız. \\
& Türklerin duygusallığı & Bu yüzden ben kendimi bu kültüre adapte etme yolunu seçtim, böyle de \\
& yapmak gerekiyor. Yaşadığım zorluklardan birisi de içinde olduğum \\
& kültürün dilini bilmememden kaynaklandı."(Avusturyalı Yönetici)
\end{tabular}

"Dil tabii ki en büyük zorluk. Mimikleri, ses tonunu, vücut hareketlerini anlayamamak gerçekten büyük bir zorluk. Dili öğrenmeye başladıktan sonra gelenekleri, yaşam tarzını öğrenmeye çalışmak ve kendini adapte etmeye çalışmak büyük bir zorluk. Aynı dili konuşsan bile iletişimde problemler yaşanabiliyor." (İspanyol Yönetici 1)

"En büyük zorluk iletişimdir. İyi bir şekilde iletişim kurabiliyorsanız, sizden ne beklendiğini ve sizin ne beklediğinizi açık bir şekilde karşı tarafa iletebiliyorsanız, her şey mümkün. Türkçe bilmemem yaşadığım zorluklardan biridir." (İspanyol Yönetici 2)

Türk Çalışanları Motive Açık ve içten olmak, Eden Unsurlar dinlemek, onları düşündüğünü hissettirmek ve dokunmak
"Çalışanı güdüleyen araçların kültürden kültüre değiştiğini düşünmüyorum. Çalışanları motive etmek kalpten gelen bir şeydir. Onları düşündüğünüzü, önemsediğinizi hissettirmenizdir önemli olan. Bunun kültürle bir ilgisi yok çünkü aynı kültürde bulunan insanlar da birbirinden farklıdır." (Avusturyalı Yönetici)

"Bu kültürde çalışanları güdülemenin yolu her şeyden önce açık olmaktır. Türk kültüründe çalışanlarla konuşurken onlara dokunmak, onları övmek, neşeli olmak diyebilirim. Ve de onları dinlemek ve örnek olmak." (Alman Yönetici 1)

"Çalışanları dinlemek ve onları anladığını göstermek önemli. Örneğin Ramazan ayında birçok çalışanım oruç tutuyor bu durumda onların mesailerinde esneklik yaratma yoluna gidiyorum. Biliyorum ki bu çalışanlar kendilerini işletmeye daha bağı hissedecek ve motivasyonları artacak." (Alman Yönetici 2) $\begin{array}{ll}\text { Çalışanlarla İnformal } & \text { İş dışında geçirilen } \\ \text { İlişkiler } & \text { zaman }\end{array}$
"Evet, zaman geçiriyoruz. Biz bir aile gibiyiz. Bir prosedür olmasından dolayı değil gerçekten 24 saati otelde geçirdiğimiz oluyor. Birlikte çalışıyoruz, yaşıyoruz ve birlikte zaman geçiriyoruz."(Avusturyalı Yönetici)

"Çok sık olmasa da evet. Uzun saatler iş yerinde oluyoruz, aileme de zaman ayırmam gerekiyor bu yüzden çok sık olmasa da zaman zaman çalışanlarla vakit geçirebiliyoruz." (İspanyol Yönetici 1)

"İş dışında çok fazla zaman geçirmiyoruz. Bunun bir nedeni, uzun saatler boyunca otelde bulunmamız. Diğeri ise ortama resmi bir hava vermek istememem, çünkü çalışanlarımla iş dışında herhangi bir aktivitede benim de o ortamda bulunduğumda benden çekinmelerini veya sıkılmalarını istemiyorum."(Italyan Yönetici 1)
Diğer taraftan yabancı yöneticilerin büyük bir kısmı, kendi kültürlerinin baskın değerlerini Türk kültürüne empoze etmek yerine farklı kültürlere açık olmak ve farklı deneyimler elde etmek gerektiğini belirtmişler ve gerektiğinde davranışlarını ortama uygun hale getireceklerini vurgulamışlardır. Yabancı yöneticilerin kendi kültürünün üstünlüğünü savunan etnosentrik görüşten uzak olduğu, bunun yerine kültürlerin olumlu yönlerini örnek alıp sinerjik bir ortam yaratmaya çalıştıkları belirlenmiştir. 
Tablo 4. Davranışsal Kültürel Zekâ Boyutuna İlişkin Bulgular

\begin{tabular}{lll}
\hline Alt Boyutlar & lçerikler & Örnek lfadeler \\
\hline Iletişim Zorlukları & Yabancı dil bilmemek, & "Dil anlamında problem yaşıyorum. Bu iletişim anlamında yaşadığım en \\
& $\begin{array}{l}\text { vücut dilini bilmemek, } \\
\text { bakış açılırının farklı } \\
\text { olması, ifade güçlüğü }\end{array}$ & $\begin{array}{l}\text { bunun için her zaman bir çözüm vardır. Türkçe bilmesem de vücut } \\
\text { hareketlerimle, kullandığım sembollerle iletişim kurmayı başarabiliyorum." } \\
\text { (Avusturyalı Yönetici) }\end{array}$
\end{tabular}

"Burada çalışanların çoğu daha önce Almanya'da çalışmış ve Almanca ve İngilizce konuşuyorlar. Ama güvenlik, teknik ve bahçe ile görevli kişiler sadece Türkçe konuşuyorlar. Onlarla iletişim konusunda sıkıntı yaşayabiliyoruz. Bence iletişimde en büyük sıkıntı dil nedeniyle yaşanır onun dışında bir problem yaşamıyoruz." (Alman Yönetici 2)

"Ben en çok vücut diliyle ilgili problem yaşıyorum. Benim hala rahatsız olduğum davranış türü bana dokunulmasıdır. Otobüste veya dışarıdayken iletişim kurmak amacıyla bana dokunulduğunda sinirleniyorum. Biliyorum ki bu kültürde sevgini veya güvenini göstermek için dokunma intiyacı hissediliyor ama beni rahatsız ediyor, çünkü böyle bir davranışın olmadığı bir kültürden geliyorum." (Hollandalı Yönetici 2) olmamak benim için önemli değildir. Kendi değerlerimi Türkiye'de yaşatmak kolay fakat benim için önemli olan yeniliklere açık olmak." (Avusturyalı Yönetici)

“Türkiye'de kendi kültürümü yaşatmak gibi bir çabam yok. Böyle bir
çabam olsa da bunun kolay olmayacağını söylemek zorundayım.
Ben global bir kültürde yaşadığımı düşünüyorum. Uzun zamandır
yabancı ülkelerde yaşıyorum ve artık global düşünüyorum bu
konuda."(Hollandalı Yönetici 1)
"Hayır, benim öyle bir çabam yok. Aksine yeni kültürleri öğrenmeye
meraklı ve istekli bir insanım.Türkiye'de yaşıyorsam bu kültürün
değerlerini öğrenmek isterim. Kendi kültürümün değerlerinin de
farkındayım ve olumlu yönlerini hep kullanacağım. Yeni karşılaştığım
kültürleri de tanımak ve olumlu yönlerini kullanmak isterim.”
(Italyan Yönetici 1)

\section{Türk Departman Müdürlerine Ait Bulgular}

Bu bölümde Türk departman müdürlerine ait demografik özellikler ve Türk departman müdürlerinin yabancı bir yöneticiyle çalışma konusundaki görüşlerine ilişkin bulgular sunulmuştur.

\section{Türk Departman Müdürlerine Ait Demografik Özellikler}

Araştırma kapsamında yer alan beş yıldızlı konaklama işletmelerinde orta ve üst düzey yönetici pozisyonunda çalışan toplam 27 Türk yöneticinin 18 'i erkek, dokuzu ise kadındır. Katılımcıların yaş ortalaması 39'dur. Araştırmaya katılan yöneticilerin büyük bir kısmının $(n=24)$ daha önce yabancı bir müdürle çalışma deneyimi vardır. Katılımcı- ların bulundukları departmana bakıldığında ise araştırmaya katılanların yedisinin insan kaynakları müdürü, beşinin önbüro müdürü, üçünün yiyecek içecek müdürü, üçünün teknik müdür, ikisinin misafir ilişkileri müdürü, ikisinin güvenlik müdürü, ikisinin muhasebe müdürü, birinin operasyon müdürü, birinin kat hizmetleri müdürü ve birinin satış pazarlama müdürü olduğu görülmektedir.

\section{Türk Departman Müdürlerinin Yabancı Bir Yöneticiyle} Çalışma Konusundaki Görüşlerine İlişkin Bulgular

Araştırmanın amacı doğrultusunda 10 konaklama işletmesi genel müdürüne bağlı olarak çalışan 27 Türk departman müdürüyle gerçekleştirilen görüşmelerin sonucunda beş konunun öne çıktığ 1 
Aslı Ersoy - Rüya Ehtiyar

Tablo 5. Türk Çalışanların Yabancı Bir Yöneticiyle Yaşadıkları Çalışma Zorluklarına İlişkin Bulgular

\begin{tabular}{|c|c|c|}
\hline $\begin{array}{l}\text { Bağıı Olduğu } \\
\text { Yabancı Yönetici }\end{array}$ & $\begin{array}{l}\text { Birlikte Çalışmanın } \\
\text { Güçlükleri }\end{array}$ & Örnek Ifadeler \\
\hline \multirow[t]{2}{*}{ Avusturyalı Yönetici } & Dil ve kültür farklııkları & $\begin{array}{l}\text { "Zorlukları var kesinlikle. Zorlukları öncelikle kültür farkı. Bizim } \\
\text { çalışanlarımızın davranış biçimleri çok farklı. Örneğin bir Almanla, } \\
\text { İsviçreliyle çalışıyorsanız daha disiplinli olmanız gerekir. Bu disipline } \\
\text { alıştıktan sonra insan yerli bir müdürle çalışmakta zorluk çekiyor bu } \\
\text { sefer de. Kesinlikle zor yönleri var ama bu sizin çalışma tarzınızla } \\
\text { alakalı diyebilirim."(Önbüro Müdürü) }\end{array}$ \\
\hline & & $\begin{array}{l}\text { "Zorlukları var tabii ki, ilk başta dil problemi. Dili çözsek, aynı dili konuşsak } \\
\text { bile kültür farklılıklarından kaynaklanan problemler yaşıyoruz. Ne demek } \\
\text { istediğimizi, buradaki işleyişi anlayamıyorlar. Aynı frekansta olamıyoruz." } \\
\text { (Teknik Müdür) }\end{array}$ \\
\hline Alman Yönetici & Dil ve kültür farklılıkları & $\begin{array}{l}\text { “Yabancı bir müdürle çalışmanın zorluğu kültür farkından ileri gelmektedir. } \\
\text { Çalışıı̆ınız birime göre belli yönetmelikler ve kanunlar var, onları } \\
\text { anlatmakta güçlük çekiyorum. Dil farkı benim için önemli...” (Teknik Müdür) }\end{array}$ \\
\hline
\end{tabular}

İspanyol Yönetici Dil ve kültür farklııkları "illk defa Türkiye’ye gelen yabancı bir müdürle çalışmanın zorlukları var elbette. Özellikle bir Avrupa ülkesinden geliyorsa oranın çalışma standartlarıyla buradakini tam oturtamıyorlar. Türk kültürünü anlamaya çalışırken bocalayabiliyorlar, personele yaklaşımlarında ama her dezavantaj bir avantaja dönüştürülebiliyor sonunda."

(İnsan Kaynakları Müdürü)

"Kültürel farklııklardan kaynaklanan zorluklar var, ama zamanla onlar da Türk kültürünü öğreniyorlar ve zorluklar ortadan kalkabiliyor. Yabancı dil açısından problem yaşıyoruz. Ben iyi derecede İngilizce bilmiyorum, bu durumda genel müdürün asistanı aracılığıyla anlaşıyoruz.."(Teknik Müdür)

\begin{tabular}{lll}
\hline Hollandalı Yönetici & $\begin{array}{l}\text { Iletişim zorlukları ve } \\
\text { sosyo-ekonomik yapının } \\
\text { anlaşılmaması }\end{array}$ & $\begin{array}{l}\text { Her ülkenin kendine göre bir yapısı vardır. Türkiye'nin de kendine özgü } \\
\text { bir ekonomik ve sosyo-ekonomik yapısı vardır. Genel olarak yabancı } \\
\text { genel müdürler ekonomik yönlerin analizini geç anlıyorlar ve ekonomik } \\
\text { konjonktür hakkında yeterince bilgi sahibi olamıyorlar.”(Muhasebe Müdürü) }\end{array}$ \\
\cline { 2 - 2 }$=$ & “...Yabancı bir müdürle çalışmanın zorlukları, kültürel farklııklardan \\
& kaynaklanan zorluklar yaşanabiliyor. En önemlisi yabancı dilden \\
& kaynaklanan iletişim problemleri yaşanabiliyor zaman zaman. Bunun \\
& yanında yöneticiniz sizin kültürünüzü tam anlamıyla öğrenmemişse \\
& sizin hareketleriniz, mimikleriniz yanlış anlaşılabiliyor.” \\
& (Misafir İlişkileri Müdürü)
\end{tabular}

İtalyan Yönetici Dil, anlam ve anlayış farkı "Yabancı bir müdürle çalışmanın zorlukları vardır tabii ki. Bu sizin altyapınıza ve deneyimlerinize bağlı.Benim zorluk yaşıyorum diyebileceğim konu iletişim olabilir. Farklı kültürlerden veya altyapılardan geliyor olmanın getirdiği birtakım zorluklar yaşanabilir, bakış açılarının farklı olması gibi." (Misafir İlişkileri Müdürü)

"Farklı bakış açısından kaynaklanan anlaşmazlıklar yaşanabiliyor zaman zaman, ama bizim genel müdürümüz farklı fikir ve görüşlere açık ve saygıyla yaklaşan bir insan ve bu anlamda bir problem yaşamıyoruz. Eğer ki iletişim kurduğunuz ortak bir dil ve de farklıııklara anlayışla yaklaşılan bir yönetim tarzı varsa sorun yaşanacağını düşünmüyorum." (Önbüro Müdürü) 
Tablo 6. Türk Çalışanların Yabancı Bir Yöneticiyle Yaşadıkları Çalışma Kolaylıklarına İlişkin Bulgular

\begin{tabular}{|c|c|c|}
\hline $\begin{array}{l}\text { Bağlı Olduğu Yabancı } \\
\text { Yönetici }\end{array}$ & $\begin{array}{l}\text { Birlikte Çalışmanın } \\
\text { Kolaylıkları }\end{array}$ & Örnek Ifadeler \\
\hline \multirow[t]{2}{*}{ Avusturyalı Yönetici } & \multirow[t]{2}{*}{$\begin{array}{l}\text { Farklı düşünce tarzı } \\
\text { ve disiplin }\end{array}$} & $\begin{array}{l}\text { "Yabancı bir yöneticiyle çalışmanın yararının olduğunu düşünüyorum. } \\
\text { Farklı düşünce tarzlarını görmek insanın vizyonunu geliştiriyor. Bunun } \\
\text { yararını karşılıklı olarak gördüğümüze inanıyorum.” } \\
\text { (İnsan Kaynakları Müdürü) }\end{array}$ \\
\hline & & $\begin{array}{l}\text { "Disiplinli ve düzenli bir şekilde çalışmayı seviyorsanız kesinlikle yabancı } \\
\text { bir müdürle çalışmak çok güzel. Daha önce yurtdışında da yaşadığım } \\
\text { için İngilizce ve Almancaya iyi derecede hâkimim, bu yüzden bir } \\
\text { sorun yaşamıyoruz."(Önbüro Müdürü) }\end{array}$ \\
\hline
\end{tabular}

\begin{tabular}{|c|c|c|}
\hline \multirow[t]{2}{*}{ Alman Yönetici } & \multirow[t]{2}{*}{$\begin{array}{l}\text { Esnek çalışma tarzı } \\
\text { ve profesyonellik }\end{array}$} & $\begin{array}{l}\text { “Aslında biz çok fazla sorun yaşamıyoruz çünkü müdürümüz Türkçe } \\
\text { konuşuyor. Yabancı yöneticiler Türk yöneticilere göre çok rahat. Bizim } \\
\text { kültürümüzde olduğu gibi ast-üst ilişkisini çok fazla yaşatmıyorlar.” } \\
\text { (İnsan Kaynakları Müdürü) }\end{array}$ \\
\hline & & $\begin{array}{l}\text { "Yerli yöneticiyle çalışmak yerine yabancı bir yöneticiyle çalışmayı } \\
\text { tercih ederim. Yabancı yöneticinin sizden istediği sadece iyi bir iş } \\
\text { yapmanız. Uzun zamandan beri yabancı yöneticilerle çalışıyorum ve } \\
\text { yabancı yöneticiler olaya profesyonelce bakıyorlar. Olayı } \\
\text { kişiselleştirmiyorlar."(Yiyecek İçecek Müdürü) }\end{array}$ \\
\hline \multirow[t]{2}{*}{ İspanyol Yönetici } & \multirow[t]{2}{*}{$\begin{array}{l}\text { Disiplin ve farklı bakış } \\
\text { açısı }\end{array}$} & $\begin{array}{l}\text { "Eğer lisana hâkimseniz, tarza hâkimseniz, ne istediğini iyi ölçebiliyorsanız } \\
\text { ve bunu anlamadığınız zaman soracak kadar medeni cesaretiniz varsa } \\
\text { yabancı bir müdürle çalışmanın hiçbir zorluğu olduğunu düşünmüyorum. } \\
\text { Tam tersine çok şeyler öğrenebileceğiniz yabancı yöneticiler vardır." } \\
\text { (Yiyecek İçecek Müdürü) }\end{array}$ \\
\hline & & $\begin{array}{l}\text { “Her şeyden önce dünyaya farklı bir açıdan bakabiliyorsunuz ve bu da iş } \\
\text { ortamında farklı fikirlerin doğmasına olanak veriyor. Bizim genel müdürümüz } \\
\text { de farklı fikirlere önem veren ve saygıyla yaklaşan biridir. Bu anlamda } \\
\text { zorluktan ziyade yararlarını gördüğümüzü söyleyebilirim. Uluslararası } \\
\text { bir zincir olduğumuz için yabancı dile hâkimiz ve bu konuda rahat bir } \\
\text { şekilde iletişim kurduğumuzu söyleyebilirim."(Önbüro Müdürü) }\end{array}$ \\
\hline \multirow[t]{2}{*}{ Hollandalı Yönetici } & \multirow[t]{2}{*}{$\begin{array}{l}\text { Profesyonellik, nesnellik } \\
\text { ve farklı düşünce tarzı }\end{array}$} & $\begin{array}{l}\text { "Ben Türklerle çalışmayı sevmiyorum. Bana göre yabancı yöneticiler } \\
\text { daha profesyonel ve nesnel. Türk müdürler olaya daha duygusal } \\
\text { yaklaşıyorlar ve de egoları daha yüksek."(Satış Pazarlama Müdürü) }\end{array}$ \\
\hline & & $\begin{array}{l}\text { “Türk kültürünü ne kadar bildiği ve buna ne kadar uyum sağladığıyla } \\
\text { ilgilidir bu. Bizim müdürümüz Türk kültürünün farkında ve herhangi bir } \\
\text { zorluk yaşamıyoruz. Aksine farklı düşünce tarzı bizi daha geniş kılıyor. } \\
\text { Müdürümüz değerlerimizin farkında olan bir yöneticidir.” } \\
\text { (Misafir İlişkileri Müdürü) }\end{array}$ \\
\hline İtalyan Yönetici & $\begin{array}{l}\text { Prensip, farklılıklara } \\
\text { açıklık }\end{array}$ & $\begin{array}{l}\text { "Yabancı bir müdürle çalışmanın artı yönlerinin olduğunu düşünüyorum. } \\
\text { Bizim genel müdürümüz farklılıklara açık ve çok saygılı bir insan ve iş } \\
\text { ortamında da son derece prensiplidir." (İnsan Kaynakları Müdürü) }\end{array}$ \\
\hline
\end{tabular}

görülmektedir: Yabancı bir yöneticiyle çalışmanın zorlukları, kolaylıkları, yabancı yöneticinin Türk kültürüne yönelik tutumu, karşılıkl kültür anlayışı, yabancı yöneticinin Türk kültürüne yönelik anlayışı ve sergilediğgi davranış ve yabancr yöneticiyle informal ilişkilerdir. $\mathrm{Bu}$ alt boyutların içerikleri ile ilgili yapılan saptamalar aşağıda tablolar halinde sunulmuştur. Öncelikle ele alınan yabancı bir yönetici ile çalışma güçlüğü konusudur. Türk departman müdürleri, yabanc1 bir müdürle çalışmanın zorluklarını dil bilmemekten kaynaklanan iletişim problemleri, anlayış farklılıkları ve kültürel farklılıklardan kaynaklanan sorunlar şeklinde sıralamaktadırlar (Tablo 5). 
Aslı Ersoy - Rüya Ehtiyar

Tablo 7. Yabancı Yöneticilerin Türk Kültürüne Yönelik Tutumlarına İlişkin Algılamalar

\begin{tabular}{lll}
\hline Bağlı Olduğu & Temel tutumlar & Örnek Ifadeler \\
Yabancı Yönetici &
\end{tabular}

Avusturyalı Yönetici

Saygı, anlayış

"Farklı kültürde ve ortamda olan insanların olaylara yaklaşım tarzları farklı olabiliyor. Biz Türk insanları olarak iş ortamında da iyi arkadaş ilişkileri geliştirmeye çalışıyoruz, sosyal faaliyetlerde bulunmaya çalışıyoruz ama aldığımız kararlara da bu duygusallıkla yaklaştığımız için profesyonelce davranamıyoruz. Genel müdürümüz bizim kültürümüz karşı saygııı ve kültürümüzü anlamaya çalışıyor diyebilirim." (Önbüro Müdürü)

"Genel müdürümüz bizim kültürümüze karşı anlayışlı davranıyor. Benim kültürüme karşı olumsuz bir şekilde davranması çatışma yaratabilir, ama çözülmeyecek bir sorun değildir." (İnsan Kaynakları Müdürü)

Alman Yönetici Anlayış, eşitlik "Genel müdürümüzün bizim kültürümüze karşı son derece anlayışla yaklaştığını ve uyumlu davrandığını söyleyebilirim. Hatta bazı özel konularda, dini bayramlar gibi bizim haberimiz olmadan hazırlık yaptırabiliyor. Genel müdürümüz kimseye ayrımcılık yapmadan kimi nasıl yöneteceğini gayet iyi biliyor." (Yiyecek İçecek Müdürü)

"Bizim inançlarımıza ve gelenek ve göreneklerimize büyük bir oranda değer veriliyor. Şu anki müdürümüz kültürümüze karşı gayet anlayışla yaklaşıyor. Örneğin, bir kurban bayramında kurban kesiliyor ve bayram kutlanıyor. Bunun yanında Ramazan ayında oruç tutan kişilere tolerans gösteriliyor. Bizim genel müdürümüz, oruç tutan personelin barda yapması gereken bir işi gerekirse kendisi barın arkasına geçip yapabiliyor." (İnsan Kaynakları Müdürü)

\begin{tabular}{ll}
\hline İspanyol Yönetici & $\begin{array}{l}\text { Saygı, uyum, anlayış, } \\
\text { olumlu yaklaşım }\end{array}$
\end{tabular}

"Bu konuda zaten bütün yabancı müdürleri hangi ülkeden olursa olsun şöyle bir genelleme yaparsak çalıştıkları yerin kültürüne ve ananelerine çok saygııılar ve o kültürün lisanını öğrenmeye, yaşantı tarzını kendilerine adapte etmeye çalışıyorlar." (Yiyecek İçecek Müdürü)

"Yabancı bir müdürle çalışmak profesyonelliği gerektiriyor ama bunun peşinden kültürümüzü anlaması ve bu doğrultuda çalışma programlarını, sektörün intiyaçlarını ve bizim yaşayabileceğimiz problemleri anlaması da önemli rol oynuyor." (İnsan Kaynakları Müdürü)

Hollandalı Yönetici Saygı, eşitlik

"Bizim müdürümüz her kültüre karşı olumlu yaklaşıyor. Bizim kültürümüze bizden daha çok saygılı davranıyor. Bizim kültürümüzde insan ayrımı yapılıyor ama bizim müdürümüzde böyle bir davranış ve önyargı kesinlikle yok. O her kültüre karşı saygılı yaklaşan bir yöneticidir."(Satış Pazarlama Müdürü)

"Genel müdürümüz son derece saygılı ve düşünceli bir insan bu konuda beni rahatsız eden bir davranışı yok."(Misafir İlişkileri Müdürü)

İtalyan Yönetici Anlayış, ilgi

"Uluslararası bir şirkette çalıştığımız için farklı kültürleri içimizde barındırıyoruz ve karşılıklı saygı çerçevesinde ortak bir anlayış geliştirebiliyoruz."(Önbüro Müdürü)

"Ben genel müdürümüzle bu anlamda bir sıkıntı yaşamıyorum. Kendisi bizim kültürümüzü öğrenme konusunda gayet istekli ve benim kültürümün değerlerini de son derece anlayışla karşılıyor." (İnsan Kaynakları Müdürü) 
Kültürel Farklılıkların Yönetiminde Kültürel Zekânın Rolü: Türk ve Yabancı Yöneticiler Üzerine Bir Araştırma

Diğer yandan yabancı dil bilen ve daha önce yabancı bir müdürle çalışma deneyimine sahip Türk departman müdürlerinin büyük bir kısmı için yabancı bir müdürle çalışmanın kolaylıkları mevcuttur (Tablo 6). Buna göre yabancı yöneticilerin farklı düşünce tarzına sahip olmaları, disiplinli ve prensipli çalışmaları, esnek çalışma tarzına sahip olmaları, farklılıklara değer vermeleri, profesyonellik anlayışları ve tarafsızlıkları bu yöneticilerle çalışmanın olumlu yönlerini oluşturmaktadır. Yabancı dil bilmeyen güvenlik müdürü ve teknik müdür pozisyonlarında çalışanların yabancı bir yöneticiyle çalışma konusunda olumlu bir görüş bildirmemeleri, algılamaların iletişim kurabilmeye bağlı olduğunu gösteren önemli bir sonuçtur.

Araştırmanın bulgularından biri de Türk departman müdürlerinin büyük bir çoğunluğunun yabanc1 yöneticinin ev sahibi kültüre yönelik olumlu bir tutuma sahip olduğunu belirtmeleridir (Tablo 7); yabancı yöneticilerin saygılı, ilgili ve anlayışlı tavırları ve ayırımcılık yapmamaları en fazla görüş birliğinin olduğu tutumlardır.

Diğer taraftan yabancı yöneticilerin kültürel toleransı ile ilgili belirtilen en önemli özelliklerinin başında kültürü anlama çabası gelmektedir. Türklerle doğrudan iletişim kurma çabası; geleneklerine duyarlı olma, uyumlu bir şirket kültürü oluşturma ve çalışanların hassasiyetlerine dikkat ederek onlar1 motive etme gibi davranışlar en fazla belirtilen hususlardır. Yabancı yöneticilerin kültürel toleransa sahip olmalarının ve kültürel duyarlılıklarının, farklı kültürlerde uzun süre çalışma deneyimleriyle ilişkili bulunduğu da önemli bir tespit olarak belirtilmektedir:

“Türk kültürünü anlayabiliyor. Örneğin, Türkçe konuşmaya çalışıyor. Cuma günü namaza gitmek isteyen personele son derece toleranslıdır. Onların davranışlarını kısıtlama gibi bir şey söz konusu değildir tam tersine kültürümüze karşı açık ve saygılıdır." (Önbüro Müdürü)

"Evet, Türk kültürünü anlayabiliyor. Her bayram, bayram kutlaması yapılır. Bayramda personele çikolata, lokum dağıtılıyor, işletmede kurban kesiliyor. Onun dtşında Ramazanda iş saatinde yemeğe gidemezsiniz gibi bir yaklaşım söz konusu değil. Çalışanların inançlarına karşı gayet saygılı ve anlayışlı davranıyor." (İnsan Kaynakları Müdürü.

“Genel müdürümüz gayet uyumlu. Ramazanda oruç tutan kişilere karşı son derece saygılı ve anlayışlıdır. Bir ülkede ne yaşanıyorsa 10 Kasım'dan tutun da Kurban Bayramma kadar buradaki insanları durumunu anlayıp ona göre hareket ediyor, gayet toplumsal bir barışıklik içinde devam ediyor." (Yiyecek İçecek Müdürü)

Türk departman müdürleri ve yabancı müdürlerin karşılıklı kültür anlayışlarının değerlendirildiği aşamada ise Türk departman müdürlerinin büyük bir kısmının yabancı yöneticiyle karşılıklı kültür alışverişinde bulundukları, birbirlerinin kültürlerini anlamaya çalıştıkları ve ortak bir kurum kültürü oluşturdukları belirlenmiştir. Departman müdürleri karşılıklı anlayış ve duyarlılık konusunu önemli bulmakta ve bu konudaki çabaların iki tarafın sorumluluğunda gelişebileceğine inanmaktadırlar:

“Bu karşılıklı oluyor. Hem biz onun kültürünü öğrenmeye çalışıyoruz hem de o bizimkini öğrenmeye çalışıyor. Bazı anlamadı ̆̆g noktalarda ise bizde böyledir sizin kültürünüzde nasıldır gibisinden sorular da soruyor ve karşılıklı bir paylaşım söz konusu oluyor." (Yiyecek İçecek Müdürü)

"Biz daha çok onun kültürünü anlamaya çaba sarf ediyoruz diyebilirim. Onlarn resmi ve dini bayramlar, aile yapıları, insan ilişkileri gibi kültürel değerleri anlamaya çalışıyoruz." (Teknik Müdür)

"Her iki taraf da özveride bulunarak birbirini anlamaya çalışıyorlar. Genel müdürümüz kendisine yabancı gelen herhangi bir şeyle, davranışla karşılaştı̆̆ında bunun anlamın mutlaka sorar. Biz de onun fikirlerini, bakış açısını kavramaya çalışırız ama o bu kültürde yaşadı̆̆ için bizim kültürümüzü daha fazla öğreniyor diyebilirim." (Insan Kaynakları Müdürü)

Türk departman müdürleri ve yabancı yöneticiler arasındaki informal ilişkilerin var olup olmadığı ile ilgili tespitlerde ise turizm sektörünün karakteristik yapısından kaynaklanan uzun çalışma saatleri ve yoğun iş temposu nedeniyle tarafların iş dışında fazla zaman geçiremedikleri, akşam yemekleri ve hafta sonu gezileri gibi sınırlı düzeyde gerçekleştirilen aktivitelerde bir araya gelebildikleri belirlenmiştir:

"Biz neredeyse günü 24 saatini otelde geçiriyoruz diyebilirim. Normal mesai saatimiz bittikten sonra misafirlerle ilgileniyoruz ve bu sayede de çalışanlar olarak hep birlikte zaman geçirme firsatımız oluyor." (Önbüro Müdürü)

"Zaten uzun saatler işteyiz, iş dışında dışarıya çıkmaya çok vakit olmuyor, ama sezon sonunda gala yemeklerimiz olabiliyor." (Insan Kaynakları Müdürü) 
"Çok sınırlı diyebilirim ve yine işin devamı niteliğinde devam eden aktiviteler, buna akşam yemekleri de dahildir."(Teknik Müdür)

\section{SONUÇ VE TARTIŞMA}

Yabancı yöneticilerin kültürel zekâsının kültürel farklılıkların yönetimi üzerindeki etkisinin belirlenmeye çalışıldığı bu araştırmada yabancı yöneticilerin bilişsel, motivasyonel ve davranışsal kültürel zekâsının kültürel farklılıkların yönetilmesinde olumlu bir etkisinin olduğu saptanmıştır.

Araştırma bulguları, yabancı kökenli yöneticilerin büyük bir kısmının Türk kültürü ve kendi kültürleri arasındaki farklılıkların bilincinde olduklarını ve bu anlamda güçlü bir bilişsel kültürel zekâya sahip olduklarını ortaya koymaktadır. Nitekim Livermore (2011) ve Brislin, Worthley ve MacNab (2006) gibi araştırmacılar; bilişsel kültürel zekâ boyutunu benzer şekilde kavramsallaştıran yazarlardır ve araştırma bulguları bu görüşleri destekler niteliktedir.

Bilişsel kültürel zekâ boyutu çerçevesinde Türk kültürü ve diğer kültürler arasındaki farklılıklar olarak betimlenen alt boyutta dikkat çekici unsurlar din, duygusallik, kurallara uymama ve genel yaşam koşulları olarak ortaya çıkmaktadır. Bilişsel kültürel zekânın önemli bir alt boyutu yerel dilin bilinmesi konusundaki gerekliliktir. Bu bağlamda araştırma bulguları ışığında; yabancı yöneticiler ile herhangi bir yabancı dili iyi düzeyde bilmeyen Türk departman müdürleri arasında anlaşabildikleri ortak bir dilin olmaması nedeniyle anlaşmazlık yaşanabildiği görülmüştür. Early ve Ang de (2003) bu boyutun varlığını görgül araştırma bulguları ile saptamış olan araştırmacılardır. Arora ve Rohmetra (2010), İngilizceyi iyi bilen ve farklı kültürlerden birileriyle etkileşimi seven bir bireyin kolaylıkla iletişime geçebildiğini, kültürlerarası ortamın gerektirdiği sözlü ve sözlü olmayan davranışları başarıyla sergileyebildiklerini belirlemiştir.

Bilişsel kültürel zekânın bir alt boyutu olarak ortaya çıkan kurumsal oryantasyon boyutu incelendiğinde; araştırmaya katılan yabancı yöneticilerin Türkiye'ye gelmeden önce ve geldikten sonra herhangi bir kurumsal oryantasyona tabii tutulmadıkları belirlenmiştir. Bunun yanında araştırmaya katılan yabancı yöneticilerin tamamının daha önce farklı ülkelerde çalışma deneyimine sahip olduğu dikkat çekmektedir. Yabancı yöneticiler, farklı ülkelerde çalışma deneyiminin kültürel uyumu kolaylaştırdığı yönünde bildirimde bulunmuşlardır. Bu sonuçlar kültürel zekâ ve yurtdışı görev tecrübesi ilişkisini görgül araştırmalara dayalı olarak inceleyen Ang, Van Dyne ve Koh (2008), Tarique ve Takeuchi'nin (2008) elde ettikleri bulgularla örtüşür niteliktedir.

Motivasyonel kültürel zekâ boyutu altında ortaya çıkan alt boyutlar; uyum sürecinde yaşanan zorluklar, Türk çalışanları motive eden unsurlar ve çalışanlarla informal ilişkiler olarak çerçevelenmiştir. Uyum sürecinde yaşanan zorluklar; yabancı dil bilmemek, vücut dilini bilmemek, iletişim problemi ve duygusallık yönünden yaşanan farklılıklardır. Yabancı yöneticilerin kültürel uyum sürecinde karşılaştıkları en önemli sorunun içinde yaşadıkları kültürün dilini bilmemeleri, bu boyut altında da kendini göstermiştir. Türk insanının duygusallık boyutundaki farklılığının anlaşılması, açık ve içten davranış, hissetmek ve çaba göstermek, dokunmak gibi özellikler bir anlamda dişi kültürün üyesi olan Türk çalışanlarını motive eden unsurlar olarak ön plana çıkmaktadır. Bu tanımlamalar, Türk kültürünün dişi kültür özellikleri ile örtüştüğünü göstermektedir. Hofstede (1980), dişi kültürün göstergelerini insanlar arası ilişkilere ve insana verilen önem şeklinde belirtmiştir. Bunun yanında, Türk departman müdürlerinin görüşleri genel olarak değerlendirildiğinde yabancı bir yöneticiden bekledikleri şeyin anlayış, disiplin ve esnek bir yönetim tarzı olduğu belirlenmiştir. Öne çıkan bu unsurların kültürlerarası uyumu ve takım uyumunu güçlendirdiği söylenebilir. Sonuçlar, Templer (2006), Lee ve Sukoco (2010) ve Tsai ve Lawrence (2011) tarafından yapılan görgül araştırmalarla ulaşılan sonuçlarla paralellik göstermektedir. Araştırmacılar, motivasyonel kültürel zekâ ile kültürel uyum arasında anlamlı bir ilişkinin olduğuna dikkat çekmekte ve motivasyonel kültürel zekâsı yüksek olan bireylerin yüksek düzeyde kültürel uyuma sahip olduğunu belirtmektedirler.

Davranışsal kültürel zekâ boyutu altında ortaya çıkan alt boyutlar ise iletişim zorlukları ve kültürel görelilik şeklinde sınıflandırılmıştır. Alt boyutlar derinlemesine incelendiğinde, Türk departman müdürlerinin büyük bir çoğunluğunun işyeri ortamında ortak bir kurum kültürü oluşturdukları ve yabancı genel müdürlerin gerektiğinde Türk kül- 
türüne uygun davranış sergiledikleri ve kendi kültürlerinin baskın değerlerini yaşatmaktan ziyade farklı kültürlere açık olmayı tercih ettikleri ve esnek oldukları belirlenmiştir. Özellikle yabancı yöneticilerin Türk insanı için önem arz eden Ramazan ayında oruç tutan personele karşı anlayışlı ve esnek davranışlar geliştirmesi bu anlamdaki uyumu güçlendiren ana unsur olarak ifade edilmiştir. Araştırma bulgularına göre; yabancı yöneticiler ve onlara bağlı çalışanların tamamının farklı değerlerle kendi değerlerini birleştiren bir yaklaşım sergilemesi her iki grubun da etnik kültürlerin üstüne çıkarak işletme içindeki kültürel farklılığın hem olumlu hem de olumsuz yönlerini algılayarak bir yaklaşım benimsediğini göstermektedir. Bu bulgular, Thomas ve Inkson (2004) tarafından gerçekleştirilen görgül araştırma sonuçları ile örtüşmektedir ki yazara göre kültürel zekâsı yüksek olan bir yönetici farklı kültürlerarası durumlarda uygun bir şekilde davranabilme yeteneğine sahiptir. Aynı zamanda Livermore (2011), kültürel zekâsı yüksek olan bir yöneticinin Ramazan ayında oruç tutan bir çalışanı nasıl idare edeceğini bildiğini ve bunu anlama yeteneğine sahip olduğunu belirtmiştir. Earley ve Gardner (2005) ise çok kültürlü takımları yöneten bir yöneticinin ekip üyeleriyle iyi ilişki kurmak için esnek bir çalışma tarzına sahip olduğunu görgül araştırma bulguları ile saptamışlardır.

Davranışsal kültürel zekânın alt boyutlarından biri olan iletişim zorlukları diğer boyutlarda saptandığ 1 üzere burada bir kez daha tespit edilmiştir. Yabancı yöneticilerin iletişim anlamında yaşadıkları sıkıntının içinde yaşadıkları kültürün dilini ve insanların vücut dilini bilmemeleri olduğu göz önüne alınırsa yabancı yönetici ve Türk departman müdürleri arasındaki etkili iletişimin yerel kültüre adaptasyonda ve iyi bir yönetim sağlanmasında etkili olduğu sonucuna varılabilir.

Elde edilen bulgular ışığında; araştırmaya katılan yabancı yöneticilerin farklı kültürel özellik taşıyan işgücünü ortak ve paylaşılan değerler etrafında birleştirebilen, kültürel farklılıkları işletmenin en önemli rekabet aracına dönüştürebilen, etnosentrik görüşten uzak durarak farklı değerlerle kendi değerlerini birleştirici bir yaklaşım benimseyen ve farklı motivasyon stratejilerini etkin bir biçimde uygulama esnekliğini gösteren vizyon sahibi bireyler olduğu belirlenmiştir. Yabancı yöneticiler, pozitif ve insani değerlerin bulundukları organizasyon- larda sürdürülmesi için çaba sarf etmektedirler. Yabancı yöneticilerin kültürel zekâsının kültürel farklılıkların yönetimine olumlu anlamda etki ettiği sonucu; yabancı yöneticilerin kültürel farkındalıkları, iletişimsel yeterlilikleri, kültürel değerler ve davranışlara karşı bilişsel yeterlilikleri, değer farklılıklarını anlayabilmeleri ve sonuç olarak farklılıklardan sinerjik kazançlar elde edebilmeleri şeklinde ortaya çıkmaktadır.

Bununla birlikte bazı sorunların da yaşandığ 1 görülmektedir. Özellikle yabancı dil konusunda yaşanan sıkıntı her üç boyutta da kendisini göstermektedir. Bu bağlamda hem yabancı yöneticilerin yerel dili bilmesi hem de Türk çalışanların evrensel dil olan İngilizce konuşma yeteneklerinin geliştirilmesi konusundaki gayretler artırılmalıdır. Çalışmanın bir diğer bulgusu ise kurumsal oryantasyon eksikliğidir. Oryantasyon eğitiminin yöneticilerin kurumu benimseme, performanslarını artırma ve yabancı bir kültüre alışma evresindeki etkisi düşünüldügünde konaklama işletmelerinin bu alandaki çalışmalara ağırlık vermeleri gerektiği söylenebilir.

$\mathrm{Bu}$ çalışmanın, konaklama işletmelerinde kültürel farklılıkların yönetiminde kültürel zekânın etkisinin belirlenmesinin hem teorik hem de pratik tartışmaların anlaşılmasına yardımcı olması ve ampirik veri sağlaması açısından önem taşıdığı düşünülmektedir. Turizmle ilgili ulusal ve uluslararası alan yazında yabancı yöneticilerin kültürel zekâsının kültürel farklılıkların yönetimine etkisine dayanan bir alan araştırmasına rastlanmamaktadır. Bu çalışma bu alandaki boşluğu doldurur niteliktedir. Bunun yanında kültürel çalışmaların birçoğu nicel araştırmalar üzerine kurulmuştur. Bu çalışmada, nitel araştırma desenlerinden elde edilen sonuçların nicel araştırmalardan elde edilen sonuçlarla karşılaştırılması bakımından alan yazına katkı sağlayacağ düşünülmektedir ve bu çalışma ile konaklama işletmeleri bağlamında kültürel zekâya ilişkin kavramsallaştırmalarda yararlanılabilecek alt boyutlar da ortaya koyulmuştur.

Her kültürü temsil eden yabancı yönetici sayısının az olması ve tek kişi olarak algıları yansıtması ve yabancı yönetici sayısı bakımından Antalya ve İstanbul illeri kadar önemli olan Ankara ilinin kapsam dışında tutulması bu araştırmanın en önemli kısıtıdır. Buna rağmen elde edilen sonuçların daha geniş örneklemlerle yapılan çalışmalarda saptanan temel özellikleri desteklemesi, sınırlı örneklemle 
çalışılsa da nitel yöntemlerin son derece etkili ve keşfedici olduğunu göstermektedir. Bu alanda gelecekte yapılacak olan çalışmalar Antalya ve İstanbul dışındaki merkezleri de içine alırsa daha genel ve güvenilir sonuçlara ulaşılabilir.

\section{KAYNAKÇA}

Aksu, A. A. ve Ehtiyar, V. R. (2007). Turizm İşletmelerinde Çă̆daş Yönetim Teknikleri. Ankara: Detay Yayıncllık.

Ang, S., Van Dyne, L., Koh, C., Ng, K.Y., Templer, K. J., Tay, C. ve Chandrasekar, N. A. (2007). Cultural Intelligence: Its Measurement and Effects on Cultural Judgment and Decision Making, Cultural Adaptation, and Task Performance, Management and Organization Review, 3(3): 335-371.

Ang, S. ve Van Dyne, L. (2008). Conceptualization of Cultural Intelligence: Definition, Distinctiveness, and Nomological Network. İçinde Ang, S ve Van Dyne, L. (Eds.) Handbook on Cultural Intelligence: Theory, Measurement and Applications, Armonk, NY: M.E. Sharpe.

Ang, S., Van Dyne, L. ve Koh, C. K. S. (2006). Personality Correlates of the Four Factor Model of Cultural Intelligence, Group and Organization Management, 31: 100-123.

Arora, P. ve Rohmetra, N. (2010). Cultural Intelligence: Leveraging Differences to Bridge the Gap in the International Hospitality Industry, International Review of Business Research Papers, 6(5): 216-234.

Asunakutlu, T. ve Safran, B. (2004). Kültürel Farklılıklardan Kaynaklanan Çatışmalara Yönelik Bir Araştırma (Marmaris Turizm Sektörü Örneği), Dokuz Eylül Üniversitesi Sosyal Bilimler Enstitüsü Dergisi, 6(1): 26-49.

Black, J. S. (1988). Work Role Transitions: A Study of American Expatriate Managers in Japan, Journal of International Business Studies, 19: 277-294.

Brislin, R., Worthley, R. ve Macnab, B. (2006). Cultural Intelligence: Understanding Behaviors that Serve People's Goals, Group and Organization Management, 31: 40-55.

Caligiuri, P. M. (2000). The Big Five Personality Characteristics as Predictors of Expatriate's Desire to Terminate the Assignment and Supervisor-rated Performance, Personnel Psychology, 53(1): 67-88.

Christensen Hughes, J. (1992). Cultural Diversity: The Lesson of Toronto's Hotels, The Cornell Hotel and Restaurant Administration Quarterly, 33 (2): 78-87.

Cox, T. H., Blake, S. (1991). Managing Cultural Diversity: Implications for Organizational Competitiveness, Academy of Management Executive, 5(3): 45-57.

D'Annunzio-Green, N. (1997). Developing International Managers in the Hospitality Industry, International Journal of Contemporary Hospitality Management, 9(4/6): 199-208.

Deng, L. ve Gibson, P. (2008). A Qualitative Evaluation on the Role of Cultural Intelligence in Cross-Cultural Leadership Effectiveness, International Journal of Leadership Studies, 3(2): 181-197.

DuPlessis, Y. (2011). Cultural Intelligence as Managerial Competence, Alternation, 18(1): 28-46.

Earley, P. C. ve Mosakowski, E. (2004). Cultural Intelligence, Harvard Business Review.
Early, P. C. ve Ang, S. (2006). Cultural Intelligence: Individual Interactions Across Cultures, Academy of Management Review, 31(2): 489-502.

Early, P. C. ve Ang, S. (2003). Cultural Intelligence across Cultures. CA: Stanford Üniversitesi Yayınları.

Early, P. C. ve Peterson, R. S. (2004). The Elusive Chameleon: Cultural Intelligence as a New Approach to Intercultural Training for the Global Manager, Academy of Management Learning EEducation, 3(1): 100-115.

Earley, C. ve Gardner, H. (2005). Internal Dynamics and Cultural Intelligence in Multinational Teams, Advances in International Management, 18: 3-31.

Earley, P. C. (2002). Redefining Interactions across Cultures and Organizations: Moving Forward with Cultural Intelligence, Research in Organizational Behavior, 24: 271-99.

Ehtiyar, R. (2003). Kültürel Sinerji: Uluslararası İşletmelere Yönelik Kavramsal Bir Değerlendirme, Akdeniz Üniversitesi İktisadi ve İdari Bilimler Fakültesi Dergisi, 3 (5): 66-78.

Groves, K. S. ve Feyerherm, A. E. (2011). Leader Cultural Intelligence in Context: Testing the Moderating Effects of Team Cultural Diversity on Leader and Team Performance, Group \& Organization Management, 36(5): 535-566.

Harris, M. M. (2006). Global forum: Cross Cultural Skill: An Emerging Construct for the 21st Century, The Industrial Organizational Psychologist, 44 (2): 49-52.

Hofstede, G. (1998). Identifying Organizational Subcultures: An Empirical Approach, Journal of Management Study, 35(1): 1-12.

Hughes, J. G. (1999). The Use of Studies to Enhance Diversity Management Effectiveness. Council for Hospitality Research Conference. Surrey University, Guildford.

İslamoğlu, A. H. (2009). Sosyal Bilimlerde Araştırma Yöntemleri. İstanbul: Beta Basım Yayım Dağıtım A.Ş.

Kanfer, R. ve Heggestad, E. D. (1997). Motivational Traits and Skills: A Person-centered Approach to Work Motivation, Research in Organizational Behavior, 19: 1- 56.

Kim, Y. J. ve Van Dyne, L. (2012). Cultural Intelligence and International Leadership Potential: The Importance of Contact for Members of the Majority, Applied Psychology: An International Review, 61: 272-294.

Kirk, J. ve Miller, M. L. (1986). Reliability and Validity in Qualitative Research. Beverly Hills, CA: Sage.

Lee, L. Y. ve Sukoco, B. M. (2010). The Effects of Cultural Intelligence on Expatriate Performance: The Moderating Effects of International Experience, The International Journal of Human Resource Management, 21(7): 963-981.

Lundberg, C. ve Woods, R. (1990). Modifying Restaurant Culture: Managers as Cultural Leaders, International Journal of Contemporary Hospitality Management, 2(4): 5-13.

Livermore, D. (2011). The Cultural Intelligence Difference, Master One Skill You Can't Do Without in Today's Global Economy. American Management Association.

MacClachlan, M. (2011). Cultural Intelligence: A Necessity for Working Effectively Across Cultures. http://www.communicaid.com/cross-cultural-training/blog/cross culturaltraining/cultural-intelligence-a-necessity-for-working-effectivelyacross-cultures, Erişim tarihi: 12 Eylül 2013. 
Maxwell, G., McDougall, M., Blair, S. (2000). Managing Diversity in the Hotel Sector: The Emergence of a Service Quality Opportunity, Managing Service Quality, 10(6): 367-73.

Miles, B. M. ve Huberman, A.M. (1994). Qualitative Data Analysis: An Expanded Source Book. Kaliforniya: Sage Yayınları.

Mok, C., Pine, R. ve Pizam, A. (1998). Work Values of Chinese Hotel Managers, Journal of Hospitality $\mathcal{E}$ Tourism Research, 21 (3): 1-16.

Proctor, T. (2005). Pazarlama Araştırmasının Temelleri. İstanbul: Bilim Teknik Yayınevi.

Rockstuhl, T., Seiler, S., Van Dyne, L. ve Annen, H. (2011). Beyond General Intelligence (IQ) and Emotional Intelligence (EQ): The Role of Cultural Intelligence (CQ) on CrossBorder Leadership Effectiveness in a Globalized World, Journal of Social Issue, 67(4): 825-840.

Rugman, A. M. ve Hodgetts, R. M. (1995). International Business: A Strategic Management Approach. Softcover, Financial Times Management.

Sadeghian, E. (2011). Presentating of the Effectual Cultural Intelligence Model of Manager on Effectiveness Iran Khodro Organization of Iran, European Journal of Scientific Research, 61 (3): 402-403.

Seymen, O. A., (2005). Örgütlerde Kültürel Çeşitlilik Olgusu, Boyutları ve Etkin Yönetimi Konusunda Farklı Yaklaşımlar: Yazınsal Bir Derleme, İşletme İktisadi Enstitüsü Yönetim Dergisi, 16 (50): 3-23.

Şahin, F. ve Gürbüz, S. (2012). Kültürel Zekâ ve Öz-Yeterliliğin Görev Performansı ve Örgütsel Vatandaşlık Davranışı Üzerinde Etkisi: Çokuluslu Örgüt Üzerinde Bir Uygulama, İş Güç Endüstri İlişkileri ve İnsan Kaynakları Dergisi, 14(2): 123-140.

Şahin, F. (2011). Liderin Kültürel Zekâsının Astların Örgütsel Vatandaşlık Davranışı ile İş Doyumu Üzerine Etkisi, Savunma Bilimleri Dergisi, 10(2): 80-104.

Tan, J. S. (2004). Issues \& Observations: Cultural Intelligence and the Global Economy, Leadership in Action, 24 (5): 19-21.

Tarique, I. ve Takeuchi, R. (2008). Developing Cultural Intelligence: The roles of International Nonwork Experiences. İçinde Ang, S. ve Van Dyne, L. (Eds.), Handbook of Cultural Intelligence: Theory, Measurement, and Applications. M.E. Sharpe, Inc., Armonk.

Tay, C.,Westman, M., ve Chia, A. (2008). Antecedents and Consequences of Cultural Intelligence Among Short-term Business Travelers. İçinde Ang, S. ve Van Dyne, L. (Eds.), Handbook on Cultural Intelligence: Theory, Measurement and Applications. Armonk, NY: M.E.: 126-144.

Tekbıyık, A. ve Akdeniz, A. R. (2008). İlköğretim Fen ve Teknoloji Dersi Öğretim Programını Kabullenmeye ve Uygulamaya Yönelik Öğretmen Görüşleri, Necatibey Eğitim Fakültesi Elektronik Fen ve Matematik Eğitimi Dergisi, 2(2): 23-37.
Templer, K. J., Tay, C. ve Chandrasekar, N. A. (2006). Motivational Cultural Intelligence, Realistic Job Preview, Realistic Living Conditions Preview, and Cross-cultural Adjustment, Group and Organization Management, 31(1): 154-173.

Thomas, D. C. ve Inkson, K. (2004). People Skills for Global Business. Berrett-Koehler Publishers.

Thomas, D. C., Elron, E., Stahl, G., Ekelund, B. Z., Ravlin, E. C., Cerdin, J.-L., Poelmans, S., Brislin, R., Pekerti, A., Aycan, Z., Maznevski, M., Au, K., ve Lazarova M. B. (2008). Cultural Intelligence: Domain and Assessment, International Journal of Cross Cultural Management, 8: 123-143.

Triandis, H. C. (2006). Cultural Intelligence in Organizations, Group and Organization Management, 31: 20-26.

Trompenaars, F. ve Hampden-Turner, C. (1997). Riding the Waves of Culture. Londra: Nicholas Brealey Yayınlar1.

Tsai, T. ve Lawrence, N. (2011). The Relationship between Cultural Intelligence and Cross-Cultural Adaptation of International Students in Taiwan, International Conference on Management, Penang, Malezya: 569-583.

Türnüklü, A. (2000). Eğitimbilim Araştırmalarında Etkin Olarak Kullanılabilecek Nitel Bir Araştırma Tekniği: Görüşme, Kuram ve Uygulamada Eğitim Yönetimi Dergisi, 6 (24): 543559.

Van Dyne, L., Ang, S. ve Livermore, D. (2010). Cultural Intelligence: A Pathway for Leading in a Rapidly Globalizing World. İçinde Hannum, K. M.,McFeeters, B. AndBooysen, L. (Eds.), LeadershipAcrossDifferences: 131-138.

Van Dyne, L.,Ang, S., Ng, K. Y., Rockstuhl, T., Tan, M. L. ve Koh, C. (2012). Sub-Dimensions of the Four Factor Model of Cultural Intelligence: Expanding the Conceptualization and Measurement of Cultural Intelligence, Social and Personality Compass, 6(4): 295-313.

Van Dyne, L., Ang, S., Koh, C. (2008). Development and Validation of the CQS: The Cultural Intelligence Scale. İçinde Ang, S. ve Van Dyne, L. (Eds.), Handbook on Cultural Intelligence: Theory, Measurement and Applications. Armonk, NY: M.E.: 126-144.

Vedadi, A., Kheiri, B. ve Abbasalizadeh, M. (2010). TheRelationshipbetweenCulturalIntelligenceandAchievement: A Case Study in an Iranian Company, Iranian Journal Management Studies, 3(3): 25-40.

Vincere, A. A. (1995). The Cyles of Global Leadership, American Journal of Management, 1(3): 227-243.

Yeşil, S. (2009). Kültürel Farklılıkların Yönetimi ve Alternatif Bir Strateji: Kültürel Zekâ, Karamanoğlu Mehmet Bey Üniversitesi İktisadi ve İdari Bilimler Fakültesi Dergisi, 11(16): 100-131.

Yıldırım, A. ve Şimşek, H. (2006). Sosyal Bilimlerde Nitel Araştırma Yöntemleri. Ankara: Seçkin Yayıncılık. 